\title{
FUNDAȚIILE UNOR CASE BUCUREȘTENE DIN SECOLELE XIX-XX, IDENTIFICATE ÎN URMA UNOR CERCETĂRI ARHEOLOGICE PREVENTIVE
}

IRINA ENE, ILEANA LĂZĂRESCU

\section{THE FOUNDATIONS OF CERTAIN BUCHAREST HOUSES FROM THE $19^{\mathrm{TH}}-20^{\mathrm{TH}}$ CENTURIES, UNCOVERED BY PREVENTIVE ARCHAEOLOGICAL RESEARCH}

The preventive archaeological excavation undertaken on the site General Constantin Budişteanu Street, no. 7, in Bucharest, from June, 29 to July, 22, 2015, revealed the vestiges of two houses with basement and brick foundations, dating from the $19^{\text {th }}-20^{\text {th }}$ centuries. On the same time, the archaeological excavation of the site confirmed the earlier habitation of the site.

KEYWORDS: Manea Brutarul Street, Stirbey Palace, foundation walls, house, $19^{\text {th }}-20^{\text {th }}$ c., cellar. XIX-XX.

CUVINTE CHEIE: Strada Manea Brutarul, Palatul Ştirbei, ziduri de fundație, casă, pivniță, secolele

\section{INTRODUCERE $^{1}$}

Terenul situat la intersecția străzilor General Constantin Budișteanu, Calea Griviței și Bulevardul Dacia a fost abandonat de zeci de ani, astfel încât astăzi nici cei mai în vârstă nu-și mai amintesc cum arătau casele care, nu cu foarte mult timp în urmă, se aflau aici. Acestea erau situate într-o zonă aproape centrală, zona galbenă a Bucureștiului de odinioară ${ }^{2}$, fiind înconjurate de mai multe edificii istorice cunoscute atunci și acum, precum biserica ridicată de Manea Brutarul, ce datează din secolul al XVIII-lea (1787), grădinile Palatului Știrbei (mijlocul secolului al XIX-lea) și alte case particulare, unele dintre ele jucând diverse roluri în cadrul comunității. Menționăm aici casa care a adăpostit Colecția Al. G. Cantacuzino (str. Budișteanu, nr. 26) ${ }^{3}$, cea în care a funcționat cantina studenților la arte plastice sau casa care a aparținut familiei regale.

Ca urmare a dorinței unor antreprenori de a reda terenului viran funcționalitatea sa urbană, pentru adresa poștală str. General Constantin Budișteanu, nr. 7, au fost realizate cercetări arheologice preventive, desfășurate în vara anului 2015, pe parcursul a două luni. Acestea au confirmat existența unor fundații de locuințe de la sfârșitul secolului al XIX-lea și începutul secolului XX, menționate în documente de arhivă, hărți vechi, precum și în literatura de specialitate.

\section{STUDIU ISTORIC}

Suprafața supusă cercetării arheologice este situată în strada General Constantin Budișteanu, la nr. 7, deși este posibil ca numerele poștale de astăzi să nu corespundă întocmai celor de la începutul secolului trecut (proprietățile putând fi parcelate și apoi vândute sau lăsate moștenire). Astăzi, ca și în trecut, Strada Budișteanu este cuprinsă între Calea Griviței/Târgoviștei ${ }^{4}$ și General Berthelot/ Fântânei, ambele fiind perpendiculare pe Calea Victoriei/ Podul Mogoșoaiei ${ }^{5}$. Practic, pentru o scurtă

\footnotetext{
${ }^{1}$ Studiul de arheologie a fost redactat de Irina Ene.

${ }^{2}$ La mijlocul secolului al XIX-lea Bucureștiul era împărțit în cinci zone: în centru era cea roșie, la nord cea galbenă, la vest cea neagră, la est cea verde, iar la sud cea albastră; vezi Potra 1941, 4.

${ }^{3}$ Ionescu 1938, 128.

${ }^{4}$ Până la Războiul de independență s-a numit Calea Târgoviștei, vezi Ionescu 1938, 190.

${ }^{5}$ Potra 1941, 12.
} 
porțiune, Calea Victoriei este paralelă cu strada Budișteanu. Dispariția la un anumit moment a construcțiilor aflate pe acest teren ai căror proprietari, Emil Dan şi Ion Martinescu, sunt menționați în parcelările din 1911 (PI. I) și lipsa informațiilor referitoare măcar la ruine, au făcut ca restabilirea planului lor să poată fi realizată numai prin cercetarea arheologică a terenului.

De asemenea, sunt cunoscute câteva informații cu privire la casa situată la numărul poștal 9 care, fiind o construcție mai mare, a rezistat mai mult timp vitregiilor vremurilor, dar nu până astăzi. Aceasta din urmă a fost ridicată inițial în stil neoclasic, fiind proiectată anterior Palatului Știrbei, pentru ca ulterior fațada să fie refăcută în stil eclectic ${ }^{6}$. Putem doar presupune că, aceasta fiind moda epocii, orășenii au încercat să imite stilul arhitectural în funcție de starea materială a fiecăruia, la o scară mai mică și fără a beneficia în mod obligatoriul de planurile unui arhitect.

După prezentarea informațiilor cunoscute la începerea proiectului ne propunem o scurtă trecere în revistă a câtorva repere cronologice cu privire la evoluţia orașului București. Începutul secolului al XIX-lea a reprezentat pentru București etapa de trecere de la Evul Mediu la Modernitate, inclusiv prin desființarea breslelor și organizarea unor școli pentru formarea arhitecților și constructorilor ${ }^{7}$. Se remarcă din ce în ce mai mult obsesia modernităţii, marcându-se totodată specificul românesc ${ }^{8}$. Cutremurul din 1802 și incendiul din 1804 din Bucureștiul insalubru au determinat autoritățile orășenești să ia măsuri pentru îmbunătăţirea construcțiilor ${ }^{9}$. Prin Regulamentele Organice (1832) a fost stabilită prima delimitare topografică a Bucureștiului, fiind evident faptul că orașul s-a extins în mahalale, unde locuitorii, în funcție de venituri, și-au ridicat case $^{10}$. Călătorii străini din secolul al XIX-lea ne dau indicii conform cărora locuințele din mahalale nu aveau mai mult de un etaj ${ }^{11}$. Spre sfârșitul secolului al XIX-lea Bucureștiul a cunoscut transformări radicale în plan edilitar: iluminat stradal, sistematizarea tramei stradale, parțiala canalizare şi pietruire a străzilor, toate sub „bagheta” primilor arhitecți români cu studii în străinătate. Încă prin Regulamentele Organice au fost stabilite criteriile pentru realizarea construcțiilor orășenești, preferându-se șindrila și cărămida, precum și instituțiile care să le avizeze ${ }^{12}$.

Strada General Budișteanu, cunoscută în secolul al XIX-lea drept Manea Brutarul, a primit actuala denumire după anul 1911. Numele străzii provine de la biserica Manea Brutarul cu hramul: Adormirea Maicii Domnului, Sfântul Gheorghe şi Sfântul Ierarh Nicolae (PI. IV/1-2). Edificiul religios, situat pe latura de nord-vest a străzii, a fost construit, „din zid”, anterior anului 1761 de Popa Radu și reconstruit între anii 1786-1787 de către Manea Brutarul starostele brutarilor şi de fiul lui Ioan Săbarul. În calitatea de ctitor dar și de staroste al breslei brutarilor s-a îngrijit de dăruirea bisericii, cât și de organizarea sărbătorilor breslei ${ }^{13}$. La 1834 zona era cunoscută ca Mahalaua Popii Radului, după numele parohului care slujea în biserică, ulterior numindu-se Manea Brutarul. În această mahala existau prăvălii pentru cele necesare desfăşurării vieții cotidiene, fără a merge la vreunul din târgurile bucureștene. Astfel documentele menționează pe cele de făinari, lumânari, săpunari, zidari, cărămidari, cârciumari ${ }^{14}$.

Dintr-o informație indirectă aflăm că între turnul-clopotniță al bisericii şi casa lui Ghiorma de pe Calea Griviței erau „câțiva zeci de paşi peste drum" "15. Din păcate despre turnul bisericii se păstrează doar informația conform căreia era „retras de la stradă”,16, precum și faptul că a fost distrus în urma bombardamentelor din București din anul 1944. Nu putem decât presupune, având în vedere proximitatea, că atunci și-au aflat sfârșitul și construcțiile de pe terenul supus cercetării arheologice și, din acest motiv, nici măcar memoria colectivă nu a mai păstrat nicio informație. Zona cuprinsă între străzile Fântânei/General Berthelot-Manea Brutarul/Budișteanu-Banului-Podul Mogoşoaiei/Calea Victoriei, constituie un perimetru semnificativ pentru Bucureşti, fapt datorat pe de o parte

\footnotetext{
${ }^{6}$ Mucenic 1997, 22.

7 Mucenic 1997, 7-8.

${ }^{8}$ Continuități, 11-13.

${ }^{9}$ Mucenic 2002, 22.

${ }^{10}$ Mucenic 2002, 9.

${ }^{11}$ Potra 1992, 257.

${ }^{12}$ Mucenic 1997, 10-12

${ }^{13}$ Iorga 2008, 199; Albumul lunei, 31.

${ }^{14}$ Documente, 155, 192, 217-222.

${ }^{15}$ Potra 1981, 339-341.

${ }^{16}$ Ionescu 1938, 191.
} 
apropierii de palatul princiar al lui Barbu Știrbei (PI. IV/3) și statutului social al proprietarilor, iar pe de altă parte construirii lăcaşului de cult al episcopatului catolic, pe terenul achiziţionat de la paharnicului Ghiţă Cantacuzino, Catedrala Sf. Iosif (1870-1884), după proiectul arhitectului german de formaţie academic-eclectică, Friederich von Schmidt ${ }^{17}$.

\section{CERCETAREA ARHEOLOGICĂ}

Cercetarea arheologică, realizată de către o echipă de la Muzeul Naţional de Istorie a României ${ }^{18}$, a debutat cu trasarea unei secțiuni de sondaj orientată SV-NE și reperarea unor structuri constructive care au determinat decaparea în suprafaţă a perimetrului investigat în vederea identificării şi punerii în valoare a acestora. În total a fost excavată o suprafaţă de aproximativ $300 \mathrm{~m}^{2}$, până la o adâncimea medie cuprinsă între $0,70-0,80 \mathrm{~m}$. În suprafața decapată au fost identificate fundațiile a trei locuințe cu pivniță, care pot fi încadrate preliminar începutului secolului XX (PI. II). La finalul cercetării a fost realizate fotografii aeriene din care au rezultat ortofotoplanuri ${ }^{19}$ (PI. III).

Stratigrafia generală a zonei este prezentată în ordine inversă, a depunerilor sedimentare, pornindu-se de la stratul superior către bază. $\mathrm{Cu}$ anumite excepţii, generate de perturbările datorate permanentei intervenţii antropice, stratigrafia generală (PI. V) se prezintă astfel:

$-0-0,50 \mathrm{~m}$ nivel de dărâmătură/nivelare cu resturi de materiale de construcție, beton, fier beton, asfalt;

$-0,50-0,80$ m nivel surprins al elevației zidurilor, nivel de călcare istoric;

- 0,80-1,20/1,80 m nivel de construcție a fundațiilor, pământ galben nisipos;

- 1,20-2,30 m nivel de pământ cenuşiu cu materiale ceramice atipice și osteologice;

- 2,30-2,40 m nivel de pământ galben, compact, fără material arheologic, steril din punct de vedere arheologic. Pe alocuri culoarea acestuia este brun negricioasă cu o consistență lutoasă.

Analiza surselor documentare indică lapidar și maniera de construcție, materialele folosite, modul în care erau construite casele particulare modeste pe o stradă dintr-o mahala bucureșteană la mijlocul secolului al XIX-lea și începutul secolului XX. Astfel, putem construi un tipar posibil: locuințele aveau un plan dreptunghiular - tip vagon, erau aliniate la trama stradală, aveau pivnițe, grădini și acareturi. Materialele de construcție folosite, conform reglementărilor legislative survenite după incendiul din 1847 erau: cărămida, piatra de var și gresia, iar pentru acoperiș tinichea sau zinc colorat ${ }^{20}$. În ceea ce privește cărămizile acestea aveau următoarele dimensiuni, impuse de municipalitate în 1855: lungime = o palmă, patru degete și 5 linii $(0,145 \mathrm{~m})$, lățime $=7$ degete și 5 linii $(0,070 \mathrm{~m})$, grosime $=3$ degete și 5 linii $(0,030 \mathrm{~m})^{21}$.

Cercetarea arheologică de teren a scos la iveală fundațiile din cărămidă a două locuințe situate pe Strada Budișteanu, datate la mijlocul secolului al XIX-lea. În ordinea descoperirii lor, de la estul la vestul străzii, au fost numite CASA1 și CASA 2, considerând prima ca fiind la numărul 7, iar cea de-a doua la numărul 5. Zidul aflat în prelungirea CASEI 2, spre est, provine de la o a treia casa, în acest moment necercetată.

CASA 1 (PI. VI), de formă dreptunghiulară, având dimensiunile maxime surprinse de $12,85 \times 8,50 \mathrm{~m}$, este orientată NE-SV, urmărind traiectul străzii Budișteanu în partea de SV. Clădirea este compusă din şapte încăperi, dintre care două se află deasupra pivniței, situată în partea de NE.

\footnotetext{
${ }^{17}$ Ionescu 1938, 128.

${ }^{18}$ Echipa de la MNIR a fost coordonată de Irina Ene, diind compusă din: Mădălina Dimache, Tudor Hila, Emil Dumitrașcu, Sorin Cleșiu, Ionuț Bocan, Decebal Vleja.

${ }^{19}$ Fotografia de acest gen nu este în nici un fel distorsionată, fiind în principiu o hartă, la care sunt ataşate puncte de referință măsurate topografic. Ulterior aceasta a fost salvată într-un format GeoTIFF, care permite ataşarea datelor georeferențiate de un fișier TIFF. Acest fișier a fost introdus în programul Global Mapper, unde a fost suprapus cu ridicarea topografică existentă, generând un plan detaliat al zonei cercetate.

${ }^{20}$ Potra 1941, 4 .

${ }^{21}$ Pănoiu 2011, 127.
} 
Cele cinci încăperi de suprafață au o fundație din cărămidă legată cu mortar ${ }^{22}$ (PI. VII), construită în groapă cu cofraj, într-un pământ galben nisipos, zidurile acestora fiind ,țesute” cu excepția a două ziduri pe latura de vest, mai mici ca dimensiuni $(0,07 \times 0,27 \mathrm{~m})$, adosate construcției și care aveau funcționalitatea unui acces care se făcea pe latura de vest. Fundația are o înălțime de $0,50 \mathrm{~m}$, iar elevația păstrată, de maxim $0,30 \mathrm{~m}$. S-a putut observa faptul că zidurile exterioare ale construcție au o grosime obținută prin așezarea unei cărămizi pe lungime și a unei pe lățime $(0,46 \mathrm{~m})$. Zidurile interioare au o grosime dată de lungimea unei cărămizi, respectiv $0,27 \mathrm{~m}$. Din cauza intervențiilor pentru amenajarea trotuarului, zidul sud-vestic exterior nu a putut fi surprins. Din elevația acestor ziduri s-au păstrat pe alocuri trei asize de cărămidă, zona fiind puternic afectată din momentul distrugerii, iar zidurile având o grosime mai mică decât a fundației. Astfel, nu pot fi precizate exact dimensiunile elevației întrucât maniera constructivă a fost una mai puțin standardizată, meșterii respectivi încercând să se adapteze amplasamentului și traiectului fundației.

Din punct de vedere constructiv cele două încăperi ale pivniței, situate în partea de NV, sunt adosate construcției de suprafață deși sunt indicii clare că au avut același moment constructiv. Accesul în acestea era realizat pe latura de nord-est, independent pentru fiecare dintre ele, putând fi surprinși parapeții care susțineau treptele. Încăperile pivniței sunt de formă dreptunghiulară, orientate ca și clădirea, NE-SV, fiind construite din interior (PI. VIII/1-2).

Cele două încăperi ale pivniţei au următoarele dimensiuni: $3 \times 3,50 \mathrm{~m}$. Parapeții s-au păstrat pe o lungime maximă de $1,15 \mathrm{~m}$, grosimea acestora fiind de $0,35 \mathrm{~m}$. La încăperea dinspre vest s-au păstrat și cele patru trepte ale scării de acces. Există indicii că podeaua acesteia era din bârne de lemn. Pe peretele de nord-est se află o răsuflătoare, iar pe celelalte câte o nișă. În dreptul nişelor $(1,75 \times 0,25 \mathrm{~m})$ zidul, care este construit ca și cele ale încăperilor de suprafață, se subțiază, având o grosime $0,15 \mathrm{~m}$. În nișa din zidul de sud-vest au fost descoperite două sticle de tipul celor de șampanie.

A doua încăpere a pivniței, situată spre est, prezintă, în interior, nișe pe fiecare dintre pereți, similare celor din încăperea vestică. Nișa dinspre est prezintă o nivelare orizontală din dale de paviment. Podeaua acesteia era din cărămidă, accesul se făcea tot pe latura de nord-est; nu s-au păstrat parapeții ci doar indicii ale celor trei trepte.

Faptul că în umplutura acestor pivnițe au fost descoperite cahle de sobă ornamentale, coșul de fum și tubulatura de ceramică, ne determină să presupunem faptul că încăperile de deasupra erau cele încălzite, deși, există posibilitatea ca după momentul distrugerii locuinței să fi avut loc o nivelare care a făcut ca materialele să se concentreze aici.

Așadar, inventarul CASEI 1 se compune din: fragmente de cahle, sticle, două pipe, ustensilele din fier necesare manevrării focului în sobă (vătraie), fragmente ceramice și de porțelan, precum și vase din tablă și email (oale, capace, polonic) databile la începutul secolului XX (PI. IX$\mathbf{X})$.

În încăperea situată în partea de sud-est am realizat un sondaj arheologic până în pământul considerat steril, fără intervenții antropice. Cercetarea arheologică a confirmat faptul că zona a fost locuită anterior ridicării construcției din cărămidă, așa cum precizează sursele istorice menționate mai sus. A fost surprinsă o groapă cu material ceramic atipic și osteologic ce poate fi încadrat sfârșitului secolului al XVIII-lea.

CASA 2, de formă dreptunghiulară, având dimensiunile maxime surprinse de $17 \times 6 \mathrm{~m}$, este orientată NE-SV, urmărind traiectul străzii Budișteanu în partea de SV, fiind situată la nord de CASA 1. Clădirea nu a putut fi cercetată integral întrucât a fost surprinsă în limita suprafeței supusă cercetării. Astfel, au fost descoperite fundațiile unei încăperi de suprafaţă, două încăperi ale pivniței, scara de acces în pivniță și fundațiile unor ziduri situate la limita proprietății.

Din încăperea de suprafață s-au păstrat două ziduri, unul care a fost parţial distrus de amenajarea trotuarului, în zona de sud-vest și unul care este zid comun cu prima încăpere a pivniței. Maniera de construcție și tehnica utilizată sunt asemănătoare CASEI 1, cu următoarele excepții: legătura dintre cărămizile zidurilor este din ciment (PI. XI), iar din punct de vedere planimetric a doua încăpere a pivniței se află în continuarea celei dintâi, la nord-est de aceasta.

\footnotetext{
${ }^{22}$ A fost realizată o analiză prin metoda fluorescență de raze X asupra a două probe de liant de zidărie.
} 
Zidul de vest al pivniței nu a putut fi surprins în întregime, fiind situat în limita suprafeței supuse cercetării. Zidul ce desparte pivnița a fost parțial distrus, păstrându-se doar o asiză de cărămidă, podeaua prezintă o șapă de ciment, zidurile în interior au fost tencuite și se pot observa urmele mai multor zugrăveli. Accesul în pivniță se află pe partea de est și se realiza probabil dintr-o curte. Cele cinci trepte au fost dublate cu bârne de lemn (PI. XII/1-2). Este posibil ca această pivniţă să fi avut funcţionalitatea de demisol locuit, chiar un depozit farmaceutic, având în vedere materialul arheologic prelevat. De asemenea, pe peretele de est sunt două răsuflători și două nișe, iar pe peretele de sud-vest și cel de nord-est câte o nișă, asemănătoare celor prezentate la CASA 1. Ultima încăpere are zidul dinspre est cu înălțimea de peste $1,20 \mathrm{~m}$, perforat de o țeavă din metal contemporană. Acesta reprezintă un zid care aparține unei a treia construcții, încă necercetată ${ }^{23}(\mathbf{P}$. XV).

Inventarul CASEI 2 se compune, de asemenea, din fragmente de cahle, sticle de diverse dimensiuni şi forme, fragmente ceramice și de porțelan, fragmente osteologice animale, precum şi vase din tablă și email (oale, capace, polonic), databile la începutul secolului XX (PI. XIII-XIV).

În zona aflată între cele două fundaţii au fost descoperite două gropi menajere situate, din punct de vedere stratigrafic, în pământul galben nisipos în care au fost construite fundaţiile, numite convenţional Cx 1 şi Cx 2.

Cx 1 este o groapă de formă ovală, cu dimensiunile $1,80 \times 0,60$ m, fără material arheologic.

Cx 2 este o groapă menajeră de formă ovală cu dimensiunile: $2,10 \times 1,70 \mathrm{~m}$, situată la est de Cx 1, secţionată de traseul unei ţevi contemporane. Materialul ceramic şi osteologic este anterior construcţiilor din cărămidă, similar celui descoperit sub fundaţiile CASEI 1 şi databil în secolul al XIX-lea.

$*$
$* *$

STUDIU ARHITECTURAL ${ }^{24}$

Obiectul studiului arhitectural de față este reprezentat de cele două clădiri din secolul al XIX-lea de la numărul 7 al străzii General Budișteanu, în zona protejată nr. 02 - Calea Griviței, situată în centrul Bucureștiului ${ }^{25}$ (Pl. XVII).

Prima reprezentare a clădirilor descoperite pe sit apare în planul din anul 1895 redactat de Institutul Geografic al Armatei ${ }^{26}$ (PI. XIX). Clădirile au o formă similară cu cea din teren, planurile oferind câteva informații ce pot clarifica situaţia existentă la momentul săpăturilor arheologice.

În planurile din 1911 clădirile sunt reprezentate fără alte modificări față de planul precedent (PI. XX). Apar în plus informații legate de adresă, de proprietar și de regimul de înălțime. Pe parcela aflată în proprietatea lui Ion Martinescu, de pe Str. Manea Brutarul nr. 5-7 (Str. General Budișteanu de astăzi) şi Calea Griviței nr. 17-19 se aflau 5 clădiri, dintre care niciuna nu a rămas în picioare până în prezent. Este cert că demolarea lor a avut loc după 1927 și înainte de 1991, când niciuna dintre construcții nu se mai regăsește în planurile cadastrale ${ }^{27}$ (PI. XXI). Trei dintre clădiri, toate desfăşurate numai pe parter, au fost descoperite în urma cercetărilor arheologice parțiale din iulie 2015, numite în continuare CASA 1, CASA 2 și CASA 3 (PI. XXII-XXVI).

\footnotetext{
${ }^{23}$ CASA 3 nu a putut fi cercetată în această etapă întrucât nu intra în perimetrul proiectului.

${ }^{24}$ Studiul de arhitectură este redactat de Ileana Lăzărescu.

25 In fosta mahala Manea Brutarul. Planul Borocczyn, 10.

${ }^{26}$ Planurile istorice anterioare, incluzând planul Borocczyn din 1846, arată o parcelă nestructurată, fără fond construitnumai vegetația fiind reprezentată. Așadar cele două locuințe pot fi datate în intervalul 1846-1895. Vezi PI. XVIII.

${ }^{27}$ Locuințele se pot vedea în aerofotografia din 1927.
} 


\section{SITUAREA CLĂDIRILOR PE PARCELĂ}

Din planurile istorice se poate observa că cele trei clădiri cercetate sunt situate pe limitele de proprietate ale parcelei. Astfel, CASA 1 are o latură pe limita de SE (comuna cu proprietatea lui M. D. Herz in 1911, în aceeași formă și pe care se află o construcție cu un plan similar celui de astăzi), iar CASA 2, pe limita de NV (în 1911 proprietatea lui Emil Dan, astăzi parcare), ambele având fațadele scurte pe aliniamentul străzii. CASA 3 este andosata casei 2 și limitei vestice ale proprietății.

Observațiile din teren corespund cu cele din planuri. Deși clădirile au fost cercetate numai parțial și doar fundațiile și pivnițele s-au păstrat până astăzi, configurația lor este similară celei descrise anterior, de unde se poate deduce că ruinele continuă până la limitele din planuri.

Așezarea pe teren a clădirilor și compoziția lor sunt tipice pentru o soluție frecventă in rândul clădirilor din secolul al XIX-lea, Casele 1 și 2 fiind așezate pe limite opuse de proprietate, în oglindă una fata de cealaltă. Exista totuși unele diferențe notabile între cele doua locuințe, ceea ce ne oferă detalii legate de construirea lor.

\section{CONFIGURAREA SPAȚIULUI INTERIOR}

Deși tot ce s-a păstrat până în prezent din cele două clădiri din faţa parcelei sunt fundațiile și pivnițele, așa cum s-a menționat anterior, o imagine a locuințelor se poate forma pe baza acestor informatii.

Ruinele păstrate până astăzi ne oferă indicii legate numai de partea de pivnițe și fundații ale acestor trei locuințe, dar sunt grăitoare pentru configurația generală a clădirilor.

Astfel, atât CASA 1, cât și CASA 2 au o alcătuire similară, dar în oglindă. În ambele accesul la subsol se făcea prin scări așezate în partea opusă străzii, CASA 2 având un singur acces așezat perpendicular pe direcția de dezvoltare a locuinței - probabil condiționat și de poziționarea casei nr. 3 ce este alipită acestei scări. În spatele casei nr. 1 s-au păstrat o scara ce coboară spre pivniță, dar și o platformă din cărămidă, dispusă simetric față de această scară, ceea ce sugerează posibila existență a unui alt acces spre subsol. Acest indiciu sugerează faptul că această casă era de fapt un ansamblu de două corpuri de clădire cuplate. Nu există indicii legate de CASA 3, din care s-au păstrat doar două ziduri perpendiculare.

La parter, accesul în CASA 1 se făcea, așa cum s-a descoperit în teren, printr-un volum andosat locuinței principale, cu o fundație lată de jumătate de cărămidă, nețesută cu restul structurii. Cel mai probabil acest volum era un hol de acces atașat locuinței, ce fie a fost adăugat ulterior primei faze de construire, fie a fost construit în aceeași fază, dar din materiale mai ușoare cum ar fi lemnul, ce nu necesitau fundații adânci. Prin corelarea cu planurile cadastrale din 1911, se poate deduce că și CASA 2 avea același tip de acces, din care însă nu ne-au rămas dovezi construite până în prezent.

La subsol, CASA 1 are, în partea opusă străzii, două camere aproximativ pătrate, de dimensiuni de circa $3,00 \times 3,50 \mathrm{~m}$ fiecare. În încăperea dinspre vest se păstrează scara din cărămidă, cu treptele din blocuri puse pe cant și parapeți lați de o cărămidă, pe care se accesa pivnița. Între cele două încăperi exista o nișă cu zidăria de jumătate de cărămidă, a cărei „țesere" vizibil mai neglijentă decât restul structurii sugerează o închidere ce s-a făcut ulterior construirii pivnițelor (PI. XXVII/1). Aceasta este o dovadă suplimentară a faptului că mai exista un acces către pivnițe, în camera de la estul celei cu scară, probabil o scară din lemn.

CASA 2 are la subsol două camere de dimensiuni similare, prima de 3,00 $\times 3,50 \mathrm{~m}$, iar a doua de $3,00 \times 3,80 \mathrm{~m}$, dispuse în anfiladă. Pivnițele se accesau pe o scară cu treptele din cărămidă așezată orizontal cu latura scurtă perpendicular pe muchia treptei și dulapi de lemn ce acționau ca tiranți pentru cei doi pereți laterali ai scării, așezați pe muchie. O parte din acești dulapi s-a păstrat până astăzi, dar este evident că aceștia erau dispuși pe fiecare treaptă spre subsol, așa cum 
sugerează locaşurile rămase după putrezirea lor (PI. XXVI/2). Parapetul scării păstrează grosimea zidului exterior din care provine, dar are un mic ornament, având cărămizile de colț teșite într-o formă de arc de cerc (PI. XXVI/3).

La parter camerele erau dispuse similar pentru CASA 1 și CASA 2, intrarea fiind prin camera centrală, față de care erau dispuse cele două camere laterale, cea principală, de dimensiuni mai mari, spre stradă și cealaltă spre spatele parcelei.

Orientarea camerelor era, prin analogie cu alte locuințe din secolul al XIX-lea dar şi constrânsă de configurația parcelei, spre stradă pentru încăperea principală și spre curte pentru cea centrală și cea secundară.

Despre CASA 3 nu există informații suficiente, întrucât cercetarea care face obiectul prezentului articol nu a vizat suprafața de teren pe care se află aceasta.

\section{STRUCTURĂ ȘI FINISAJE}

Fundațiile caselor 1 și 2 sunt din aceleași cărămizi din care s-au făcut și zidurile pivnițelor, dar blocurile sunt prinse într-o masă neregulată de mortar. Astfel, se poate deduce că procesul prin care acestea ar fi fost puse în operă ar fi următorul: s-au săpat gropile pentru fundații, în care s-au așezat blocurile de cărămidă între care mortarul a fost pur și simplu turnat, nu întins cu mistria. În urma acestui mod de construire fundațiile nu au un traseu atât de precis ca baza zidurilor de suprastructură; acestea din urmă au fost retrasate deasupra fundațiilor pentru a se păstra o formă regulată a construcției.

Zidurile pivnițelor variază de la casă la casă. Astfel, CASA 1 are zidurile perimetrale groase de o cărămidă și jumătate, iar grosimea zidurilor interioare variază între o cărămidă și o cărămidă și jumătate. În pereții perimetrali pivnițelor sunt nișe adânci de o cărămidă, folosite pentru depozitare. În pereții de pe latura de nord a pivnițelor se găsește un alt tip de nișe, cu cărămizile retrase în trepte, ceea ce sugerează existența unor ferestre cu parapeții înclinați, pentru a permite ventilarea și a lăsa mai multă lumină să pătrundă în subsol. O soluție similară se poate încă observa la pivnițele casei 2, într-o variantă mai bine conservată (PI. XXVI/4). CASA 2 are zidurile exterioare groase de o cărămidă și jumătate iar cele interioare de o cărămidă. Zidurile exterioare de la nord și sud au fiecare câte o nișă adâncă de o cărămidă, asemănătoare celor de la CASA 2.

O diferență importantă în structura celor două case analizate ține de materialul folosit pentru a lega elementele de zidărie. Astfel, CASA 1 are blocurile legate cu mortar pe bază de var, iar CASA 2 cu mortar pe bază de ciment, după cum a rezultat în urma analizelor de laborator ${ }^{28}$. Acest fapt poate sugera o eventuală cronologie a construirii celor două locuințe - cum cimentul a început să fie folosit mai recent, este probabil ca prima construită să fi fost CASA 1, iar CASA 2 să fie construită ulterior, sau că aceasta din urmă să fi fost restaurată parțial, cu păstrarea blocurilor de cărămidă originale.

Din acoperirea pivnițelor casei 1 nu s-a păstrat nici un element, dar pentru cea a casei 2 există un indiciu, păstrat la nișa cea mai apropiată de scara de acces, ce sugerează, prin dubla sa curbură și prin forma pătrată a încăperilor, că pivnițele erau acoperite cu bolți călugărești sau cu bolți semicilindrice cu penetrații. (PI. XXVI/5). Evitând să facem analogii cu alte exemple din aceeași perioadă, este totuși posibil ca ferestrele pivnițelor să fi avut arce plate la partea superioară. Pentru acoperirea camerelor casei 1, cel mai probabil s-a folosit același sistem sau o acoperire mai simplă, cu plafoane de lemn ce s-au degradat în timp-motiv pentru care nu au rămas dovezi. În planul cadastral din 1911 în spatele casei 2 este reprezentată o copertină deasupra acceselor în pivnițe, probabil un volum de lemn ce nu s-a păstrat până astăzi, ce avea rolul de a le proteja.

În pivnițele celei de-a doua case s-au păstrat și elemente de finisaj. Pereții sunt tencuiți, iar podeaua este acoperită cu o șapă de ciment sub care s-a descoperit o altă pardoseală, din cărămidă (PI. XXVI/6). Pe tencuiala din pivnițe s-au găsit urme de zugrăveală de culoare galbenă și albastră,

\footnotetext{
${ }^{28}$ Vezi nota 22 și Pl. XVI.
} 
existând mai multe straturi succesive. În CASA 1 nu s-au păstrat decât două plăci ceramice, întruna din nișele pivniței, ce proveneau de la o sobă aflată la nivelul superior (parter).

\section{CONCLUZII}

Cercetarea arheologică preventivă desfășurată în luna iulie a anului 2015, pe proprietatea situată în strada general Constantin Budișteanu la numărul 7 a pus în evidență fundațiile și pivnițele a cel puțin două case ridicate la mijlocul secolului al XIX-lea. Cea de-a treia locuință nu a fost cercetată integral, întrucât depășea perimetrul proiectului, dar prin coroborarea informațiilor se poate afirma că zidul dinspre est aparține unei alte construcții. De asemenea, în ceea ce privește CASA 1, există posibilitatea ca aceasta să fi fost compusă din două locuințe, în oglindă, după modelul epocii, având în vedere existența a două încăperi ale pivniței cu intrări diferite. $\mathrm{Cu}$ siguranță accesul, atât în CASA 1, cât și în CASA 2, se realiza printr-o curte comună, așa cum reiese din planul arheologic. Din analiza liantului s-a putut constata faptul că această locuință a suferit o refacere considerabilă, undeva după anii '30 ai secolului XX.

Conform planurilor Bucureștiului putem afirma că aceste locuințe au fost ridicate după mijlocul secolului al XIX-lea, dar momentul în care acestea dispar rămâne incert. Ceea ce se cunoaște este faptul că turnul clopotniță al bisericii Manea Brutarul a fost distrus în urma bombardamentelor din București din anul 1944. Având în vedere proximitatea, precum și fundațiile construite, care nu aparțin unor construcții foarte solide, putem considera că și acestea au avut de suferit în urma aceluiași bombardament.

Cercetarea arheologică a zonei a vizat, până în acest moment, doar vestigiile caselor situate la intersecția celor două străzi bucureștene, respectiv Manea Brutarul/General Constantin Budișteanu și Calea Târgoviștei/Calea Griviței, ridicate la confluența secolelor XIX-XX, aducând informaţii de detaliu, necunoscute până în prezent.

BIBLIOGRAFIE

Albumul lunei

Borocczyn 1846

Continuități

Documente

Ionescu 1938

Iorga 2008

Mucenic 1997

Mucenic 2002
Albumul lunei Bucureștilor 9 mai - 9 iunie 1936, Publicațiune oficială a primăriei municipiului București, Redacția și Administraţia București, 1936

Planul Bucureștiului ridicat și nivelat din porunca d-lui marelui vornic al Departamentului Trebilor din Năuntru Barbu Știrbei după întocmirea secției inginerești sub direcția specială a maiorului baron Rudolf Artur Borozin în zilele pre înaltului domn stăpânitor Gheorghe Dimitrie Bibescu V. V. Anul 1846

Continuități. Fragmente de modernitate românească în prima jumătate a secolului al 20-lea, Carmen Popescu (coord.), București, 2010

Documente pentru istoria Bucureștilor. Inceputuri edilitare 1830-1832, București, 1936

Gr. Ionescu, București, Ghid istoric și artistic cu 157 ilustrații în text și 5 planuri afară din text, Fundația pentru Literatură și Artă Carol al II-lea 1938

N. Iorga, Istoria Bucureștilor, București, 2008

Cezara Mucenic, București. Un veac de arhitectură civilă. Secolul al XIXlea, București, 1997

Cezara Mucenic, Străzi, piețe, case din vechiul București - Urbanism și arhitectură - sec. $X V-X X$, București, 2002 
Pănoiu 2011

Potra 1941

Potra 1981

Potra 1992
A. Pănoiu, Evoluția oraşului București, București, 2011

G. Potra, Bucureștii la mijlocul secolului al XIX-lea. Impresiile germanului W. Derblich, București, 1941

G. Potra, Din Bucureștiul de altădată, București, 1981

G. Potra, Bucureștii văzuți prin călătorii străini (secolele XVI-XIX), București, 1992

Fotografiile aeriene au fost realizate de către Marius Amariei, fotogrametria de către Mihai Bozgan, iar ortofotoplanul de către Mihai Florea, iar analizele de fluorescență X de către dr. Gheorghe Niculescu, tuturor acestora mulţumindu-le.

\section{LISTA ILUSTRAȚIILOR}

Pl. I. Plan cadastral (1911).

PI. II. Ridicarea topografică.

Pl. III. Ortofotoplan.

PI. IV. Fotografii: 1. Biserica Manea Brutarul. Absida altarului; 2. Biserica Manea Brutarul. Pridvor; 3. Palatul Barbu Ştirbei.

PI. V. CASA 1, profil nord: 1. Foto; 2. Desen

PI. VI. CASA 1. 1. Vedere aeriană; 2. Pivnițe

PI. VII. Imagini CASA 1. 1-2. Nişe pivnițe

PI. VIII. Imagini CASA 1: 1. Nișă pivniță; 2. Acces pivniță

PI. IX. CASA 1. Inventar

PI. X. CASA 1. Inventar

PI. XI. Imagini CASA 2. 1. Vedere aeriană; 2. Pivniță

PI. XII. Imagini CASA 2: 1. Nișă pivniță; 2. Acces pivniță

PI. XIII. CASA 2. Inventar

PI. XIV. CASA 2. Inventar

PI. XV. CASA 3. 1. Zidul de est; 2. Zidul de est perforat de conductă contemporană, detaliu

PI. XVI. Buletinul de analiză de fluorescență X a mortarului: 1. CASA 1; 2. CASA 2

PI. XVII. Localizarea sitului, pe planul de situație din 1901(carou 11D3)

PI. XVIII. Planul Borroczyn, fila 27.

PI. XIX. Locuințele pe planul redactat de Institutul Geografic al Armatei, 1895

Pl. XX. Planul cadastral din 1911, carou 11D. Clădirile descoperite în sit sunt haşurate în plan.

PI. XXI. Aerofotografia din 1927. Conturul caselor este recognoscibil.

PI. XXII. Releveul ruinelor descoperite în sit. Plan

PI. XXIII. Secțiune A-A

PI. XXIV. Secțiune B-B

PI. XXV. Secțiune C-C

PI. XXVI. CASELE 1 și 2. 1-5. Detalii

LIST OF ILLUSTRATION

Pl. I. Cadastral survey (land parcel map - 1911).

Pl. II. Land survey (plotting).

Pl. III. Ortophotomap.

PI. IV. Photos: 1. Manea Brutarul Church. The apse of the altar; 2. Manea Brutarul Church. Threhold; 3. The Barbu Știrbei Palace.

PI. V. Hose 1, North profile: 1. Photo; 2. Drawing 
PI. VI. House 1. 1. Aerial view; 2. Cellars.

PI. VII. Images House 1. 1-2. Cellar's niches.

PI. VIII. Images House 1: 1. Cellar's niche; 2. Cellar's access.

PI. IX. House 1. Inventory.

PI. X. House 1. Inventory.

PI. XI. Images House 2. 1. Aerial view; 2. Cellar.

PI. XII. Images House 2: 1. Cellar's niche; 2. Cellar's access.

PI. XIII. House 2. Inventory.

PI. XIV. House 2. Inventory.

PI. XV. House 3. 1. East wall; 2. East wall perforated by a contemporary pile, detail.

PI. XVI. The analysis bulletin for the mortar's X fluorescence: 1. House 1; 2. House 2.

PI. XVII. The site's location on lay-out on lay-out of 1901 (check 11D3).

PI. XVIII. The Borroczyn plan, foil 27.

PI. XIX. The dwellings on the plan made by Geographic Institute of the Army (1895).

PI. XX. The cadastral survey of 1911 (check 11D). The investigated buildings on the site are hachured on the plan.

PI. XXI. Aerial photo of 1927. The houses' contour (outline) is recognizable.

PI. XXII. Mapping of the ruins uncovered on site. Plan.

PI. XXIII. Section A-A

PI. XXIV. Section B-B

PI. XXV. Section C-C

PI. XXVI. Houses 1 and 2. 1-5. Details.

IRINA ENE, ILEANA LĂZĂRESCU Muzeul Național de Istorie a României Irinaene29@yahoo.com ileana.lazarescu.arch@gmail.com 


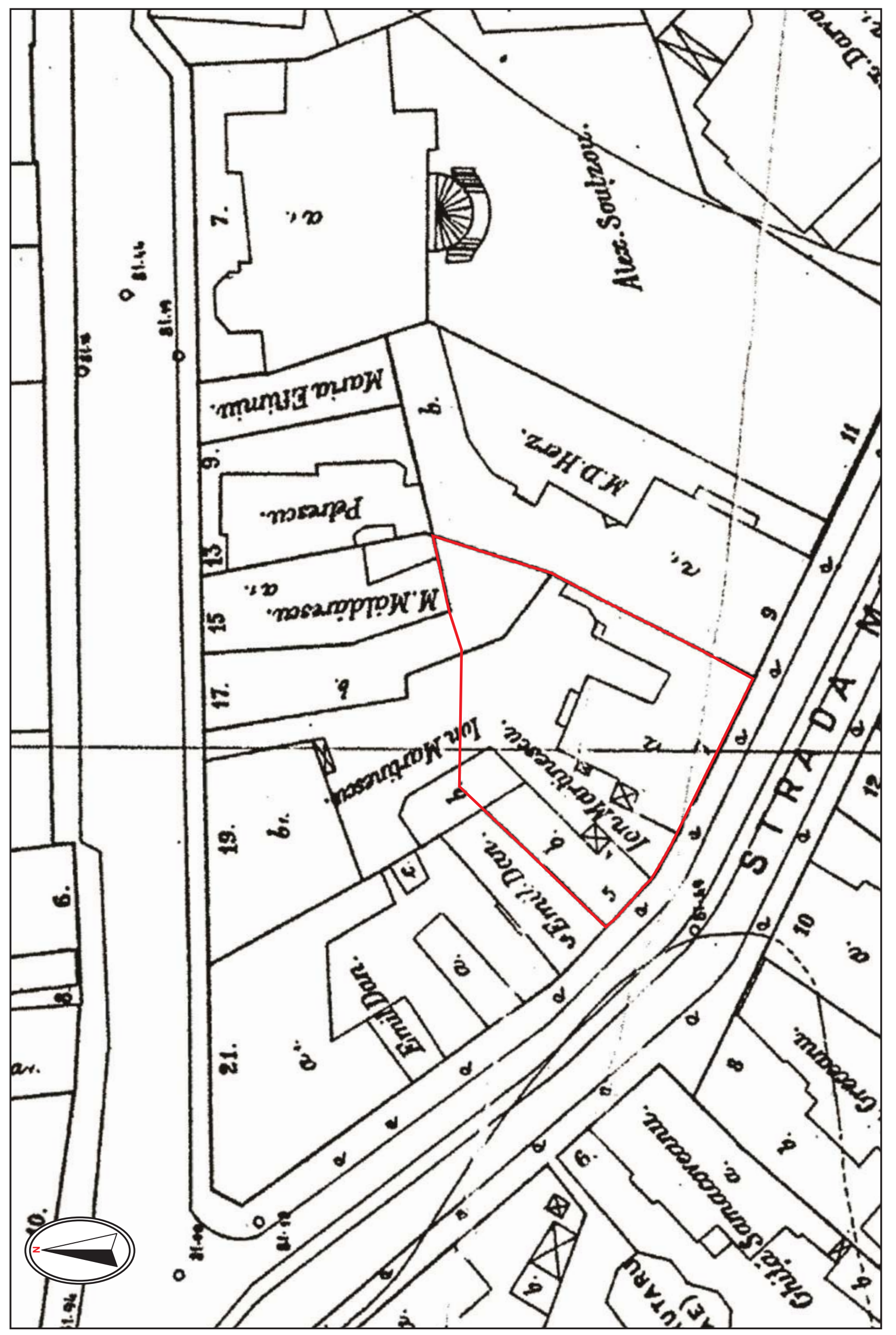

Pl. I 


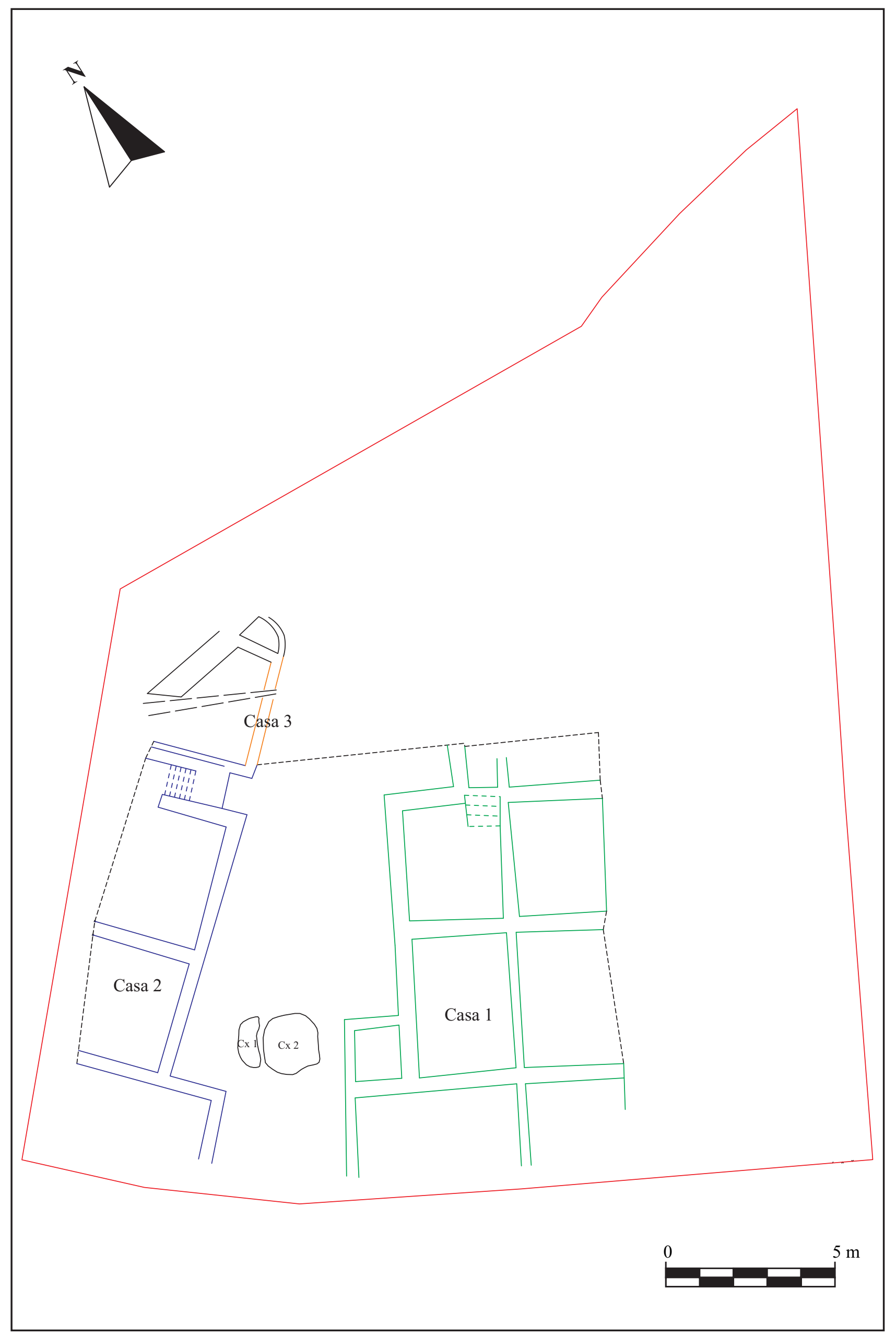

PI. II 


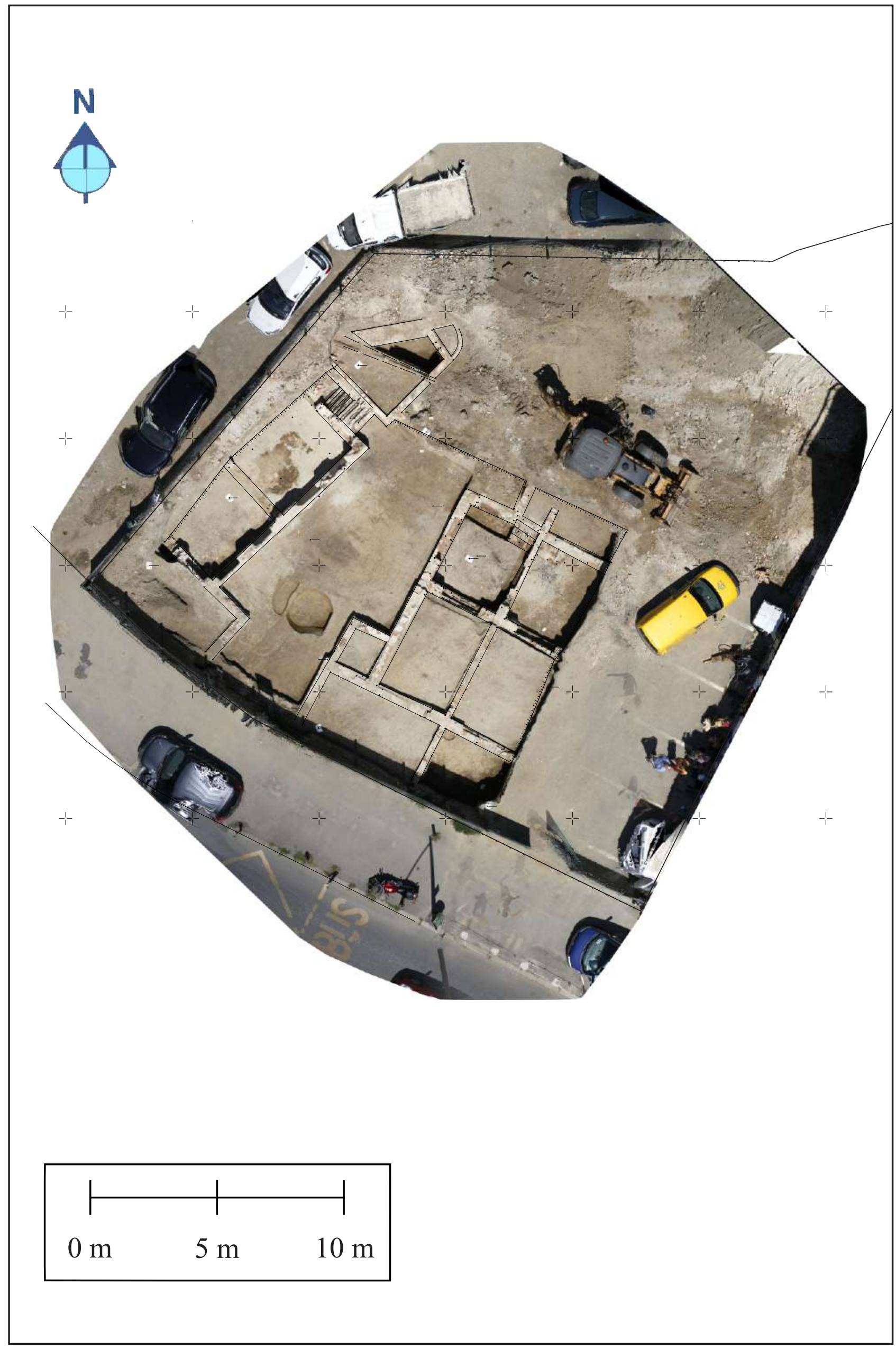

PI. III 


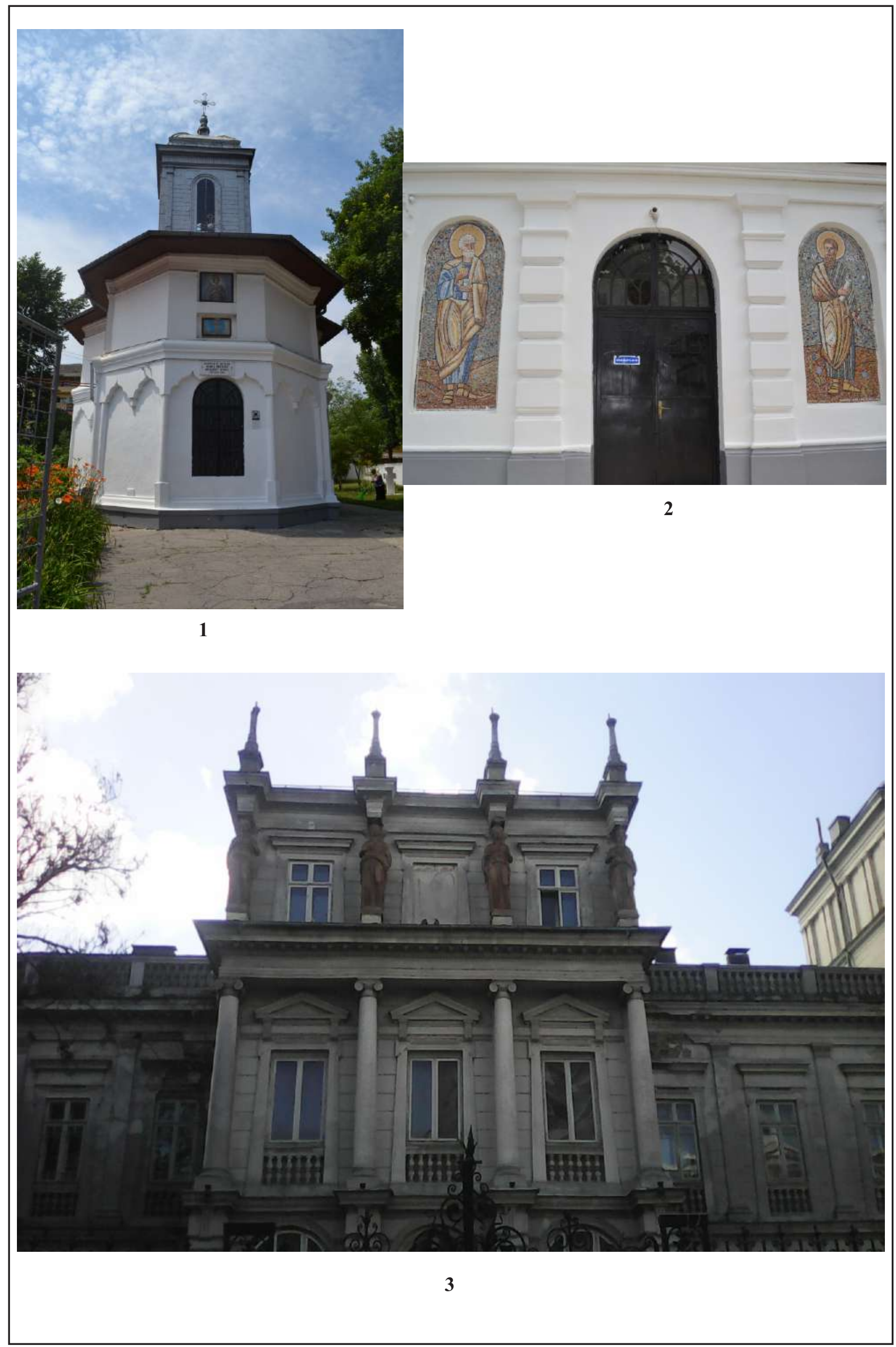

PI. IV 


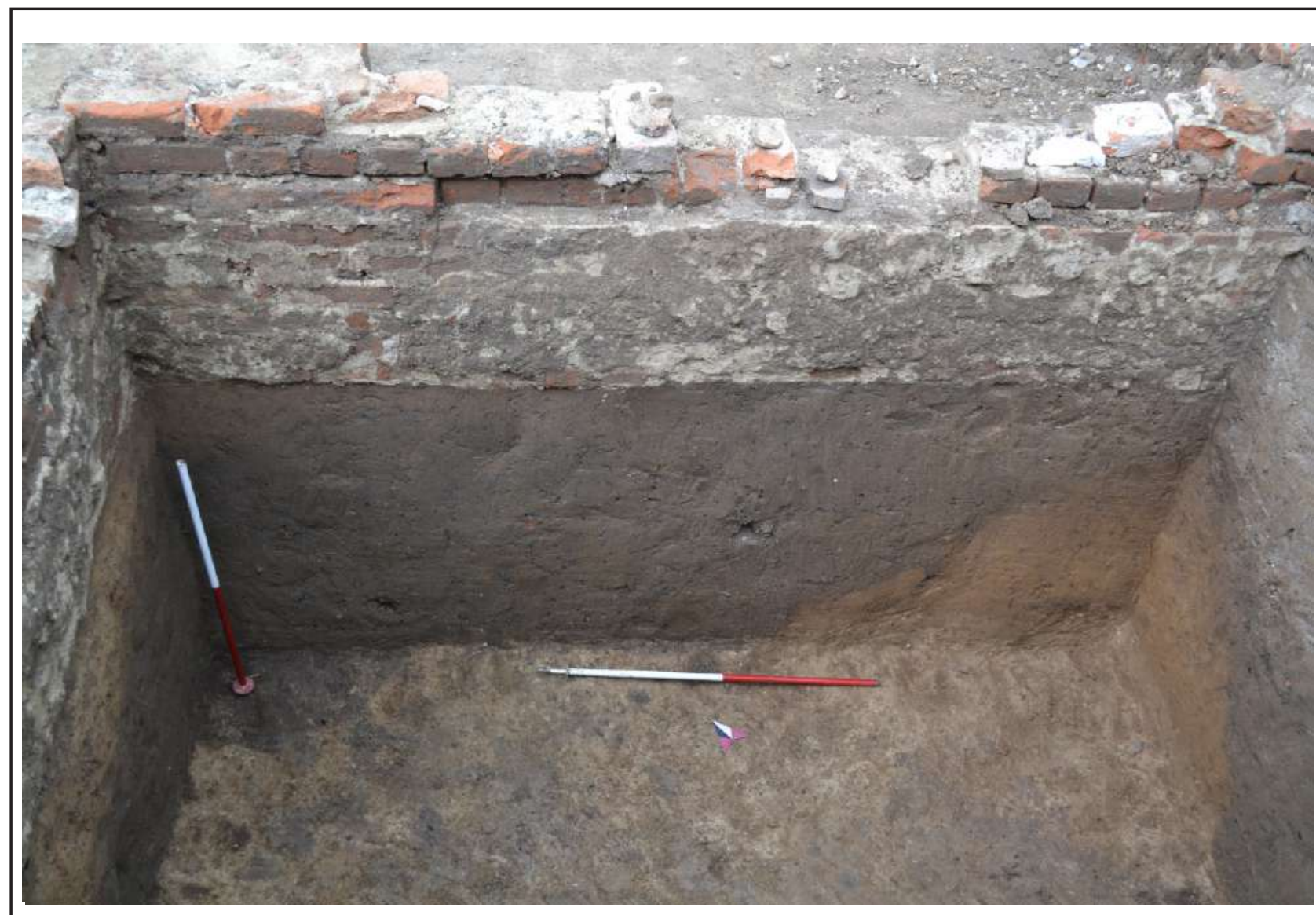

1
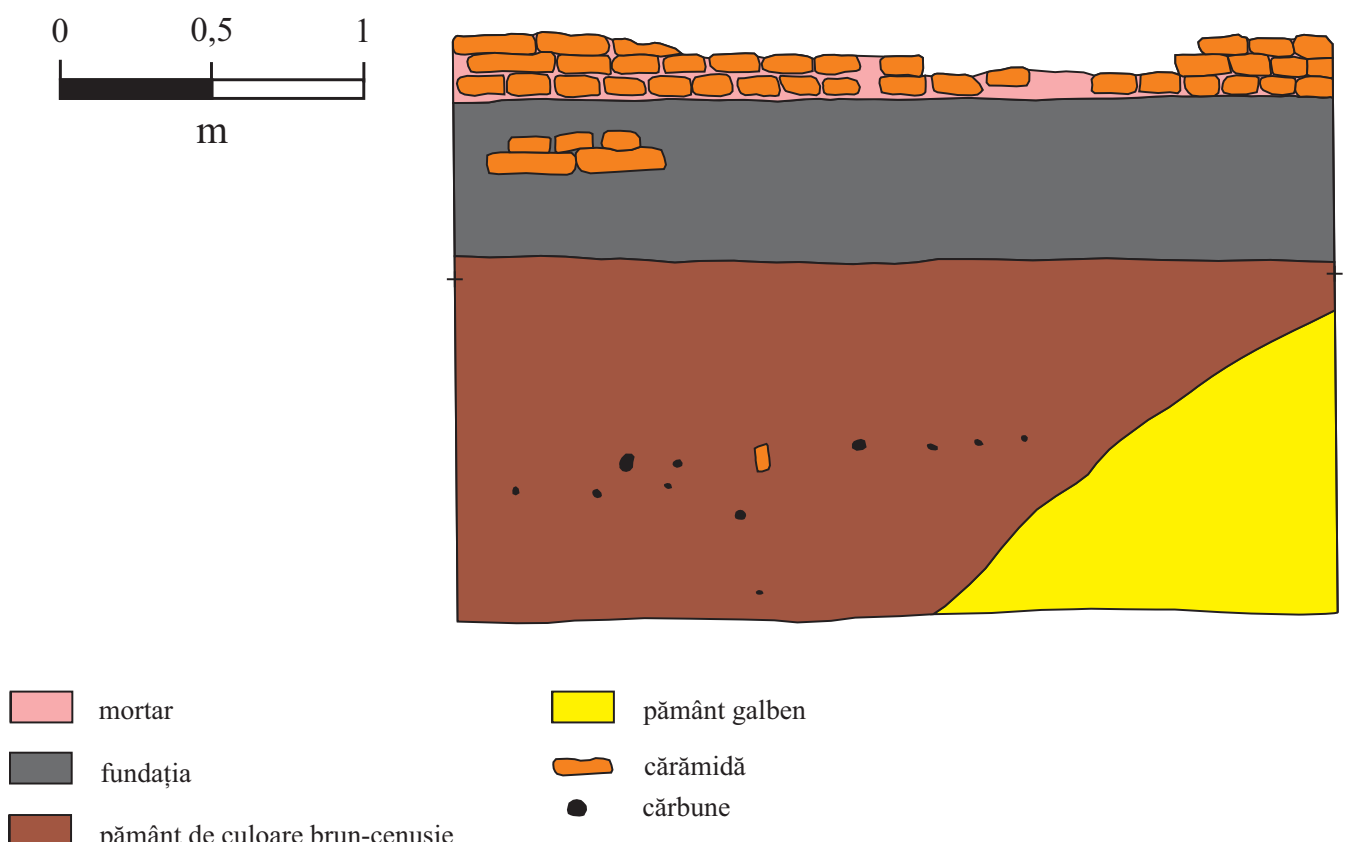

mortar

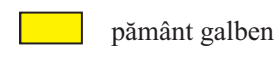

fundația

$\circlearrowright$ cărămidă

pământ de culoare brun-cenușie

- cărbune

(conține: pigmenți de cenușăa,

fragmente de cărămidă, ceramice și

oase) 


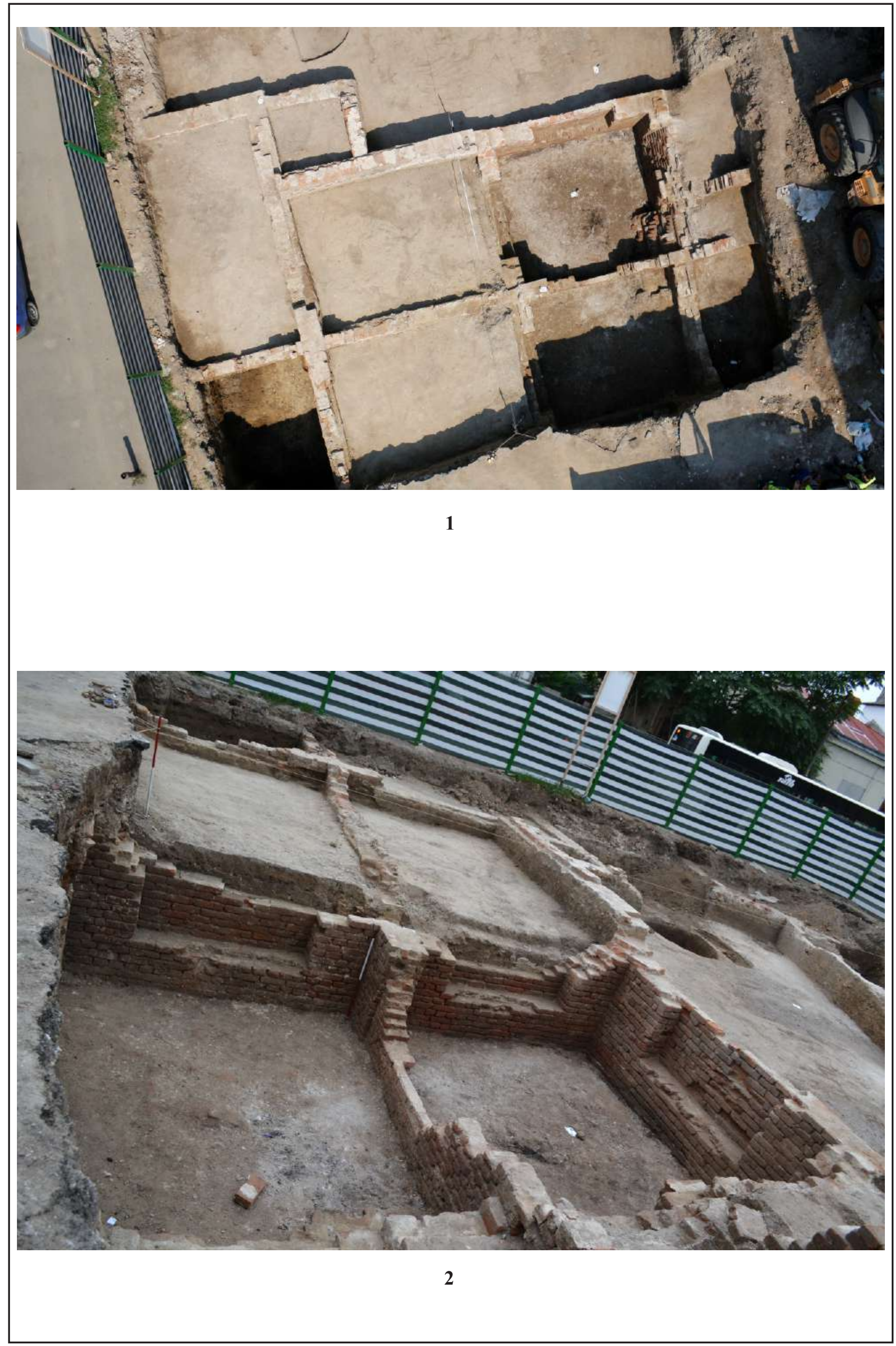

PI. VI 


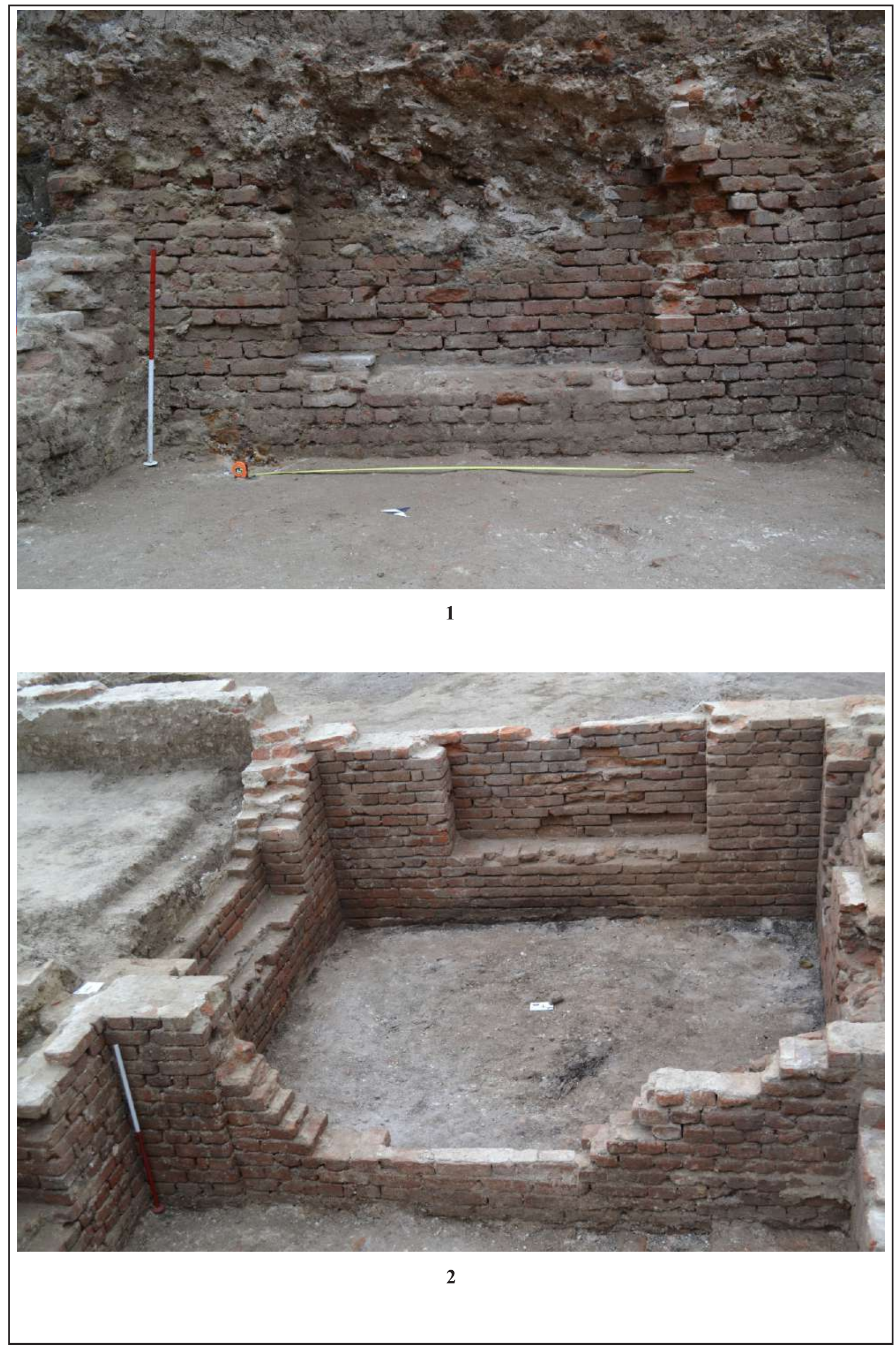

PI. VII 


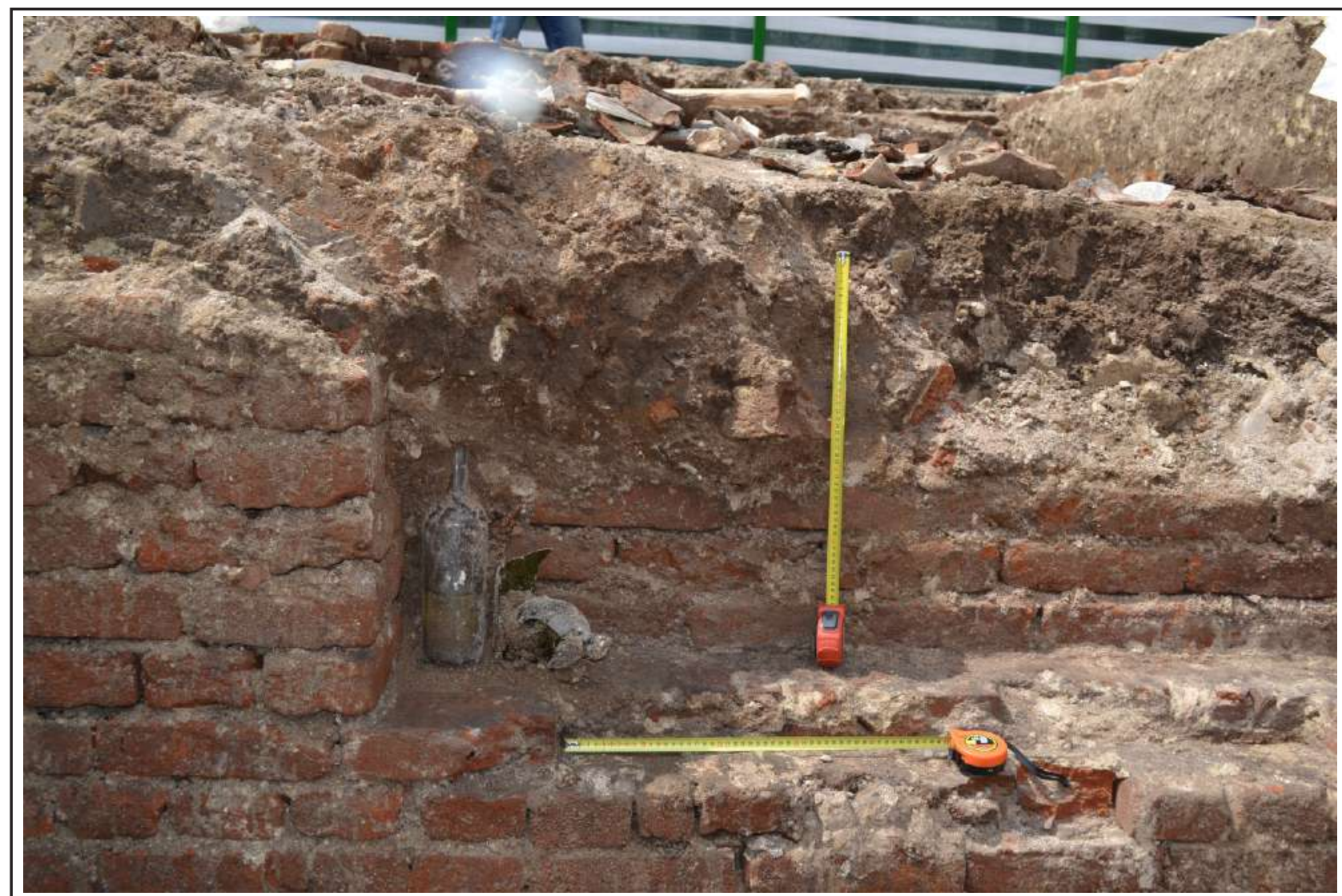

1

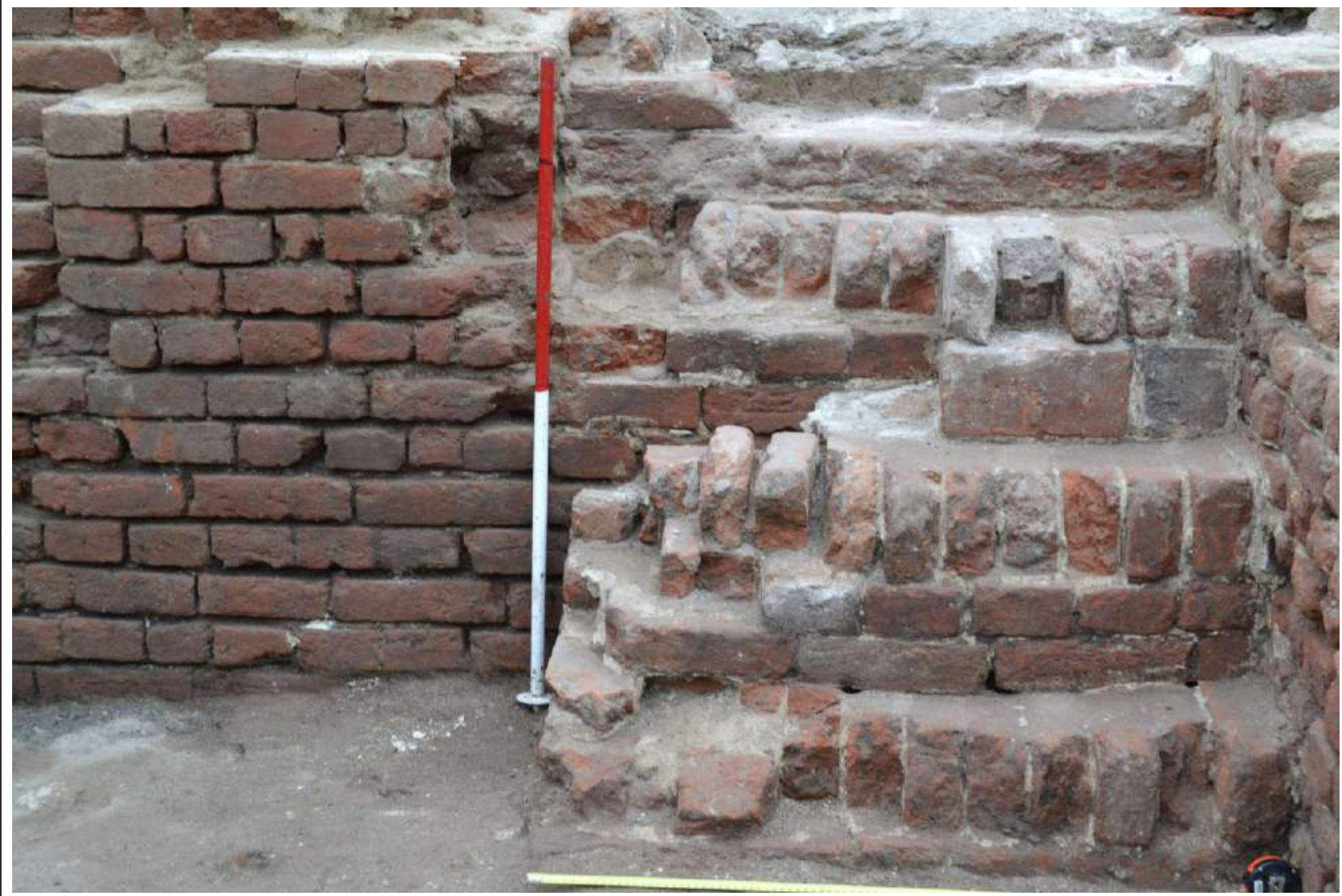




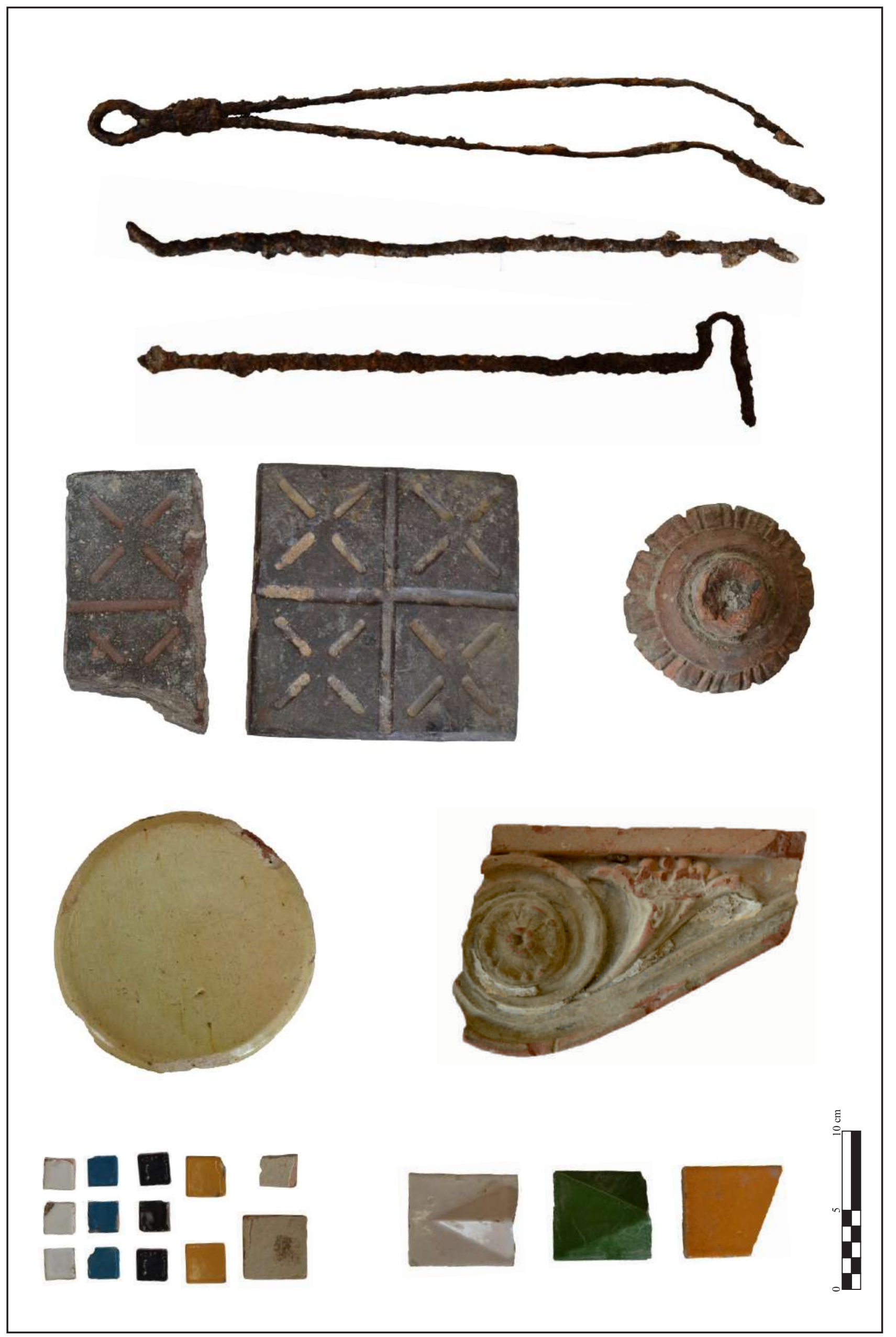

PI. IX 


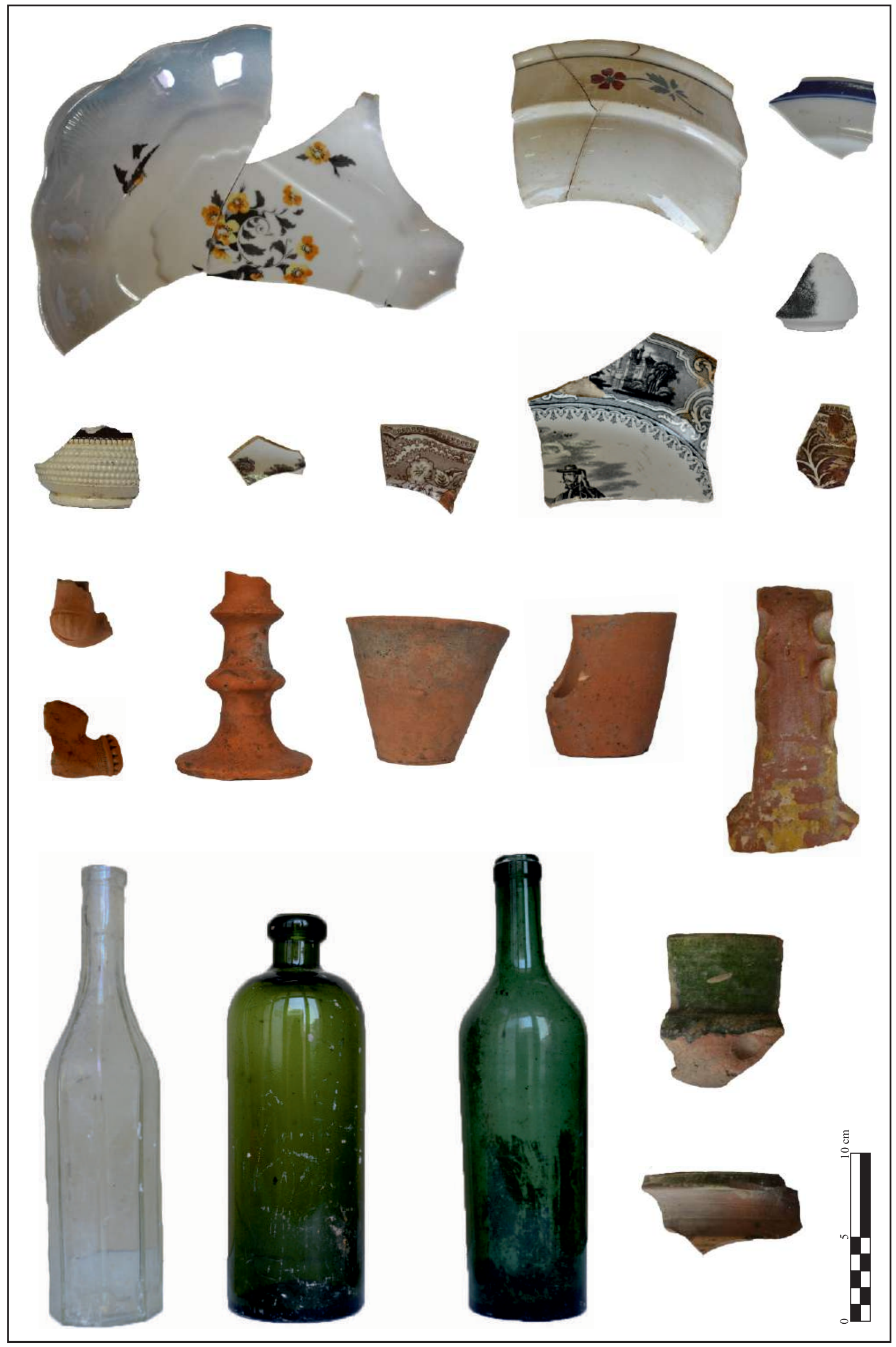

Pl. X 


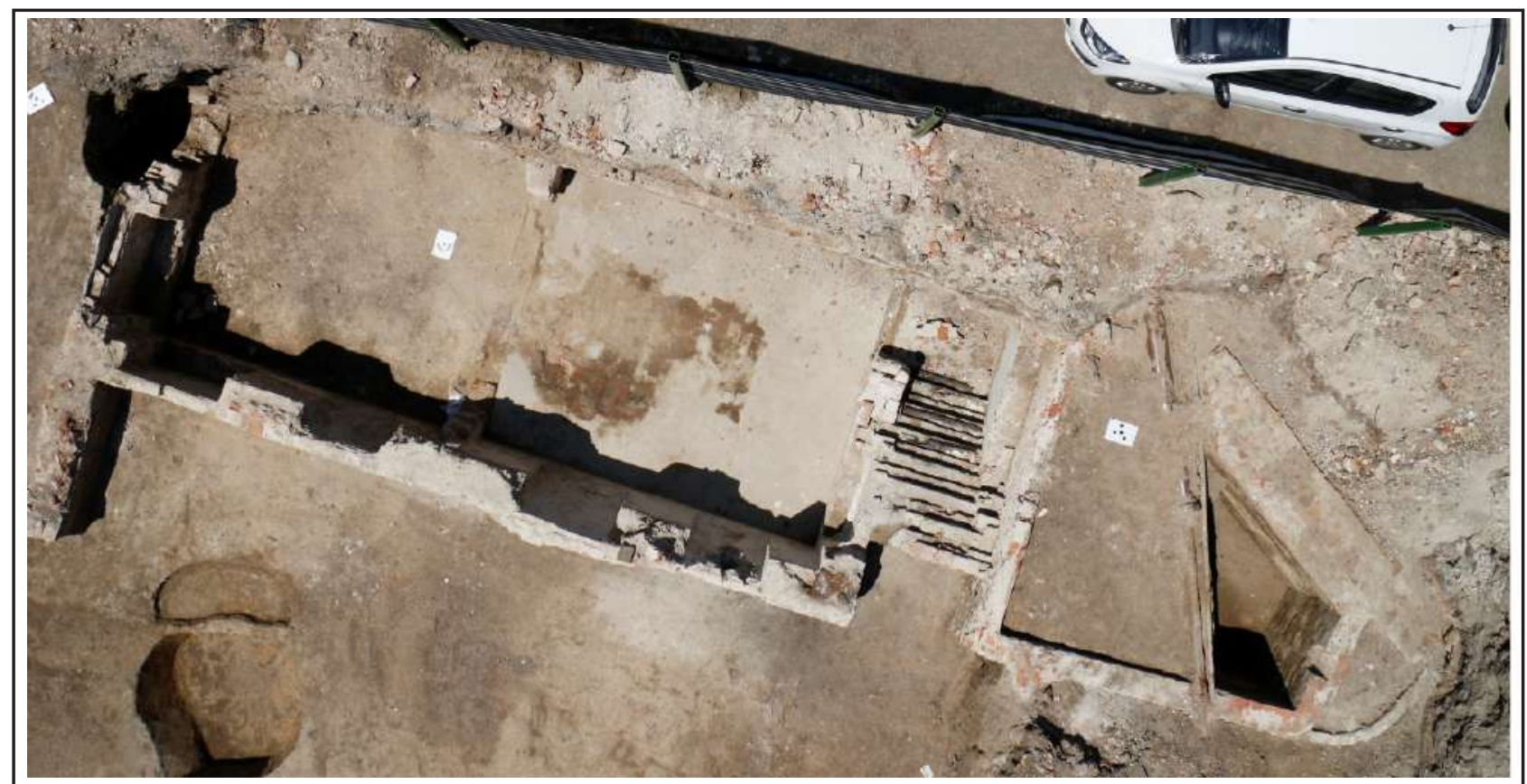

1

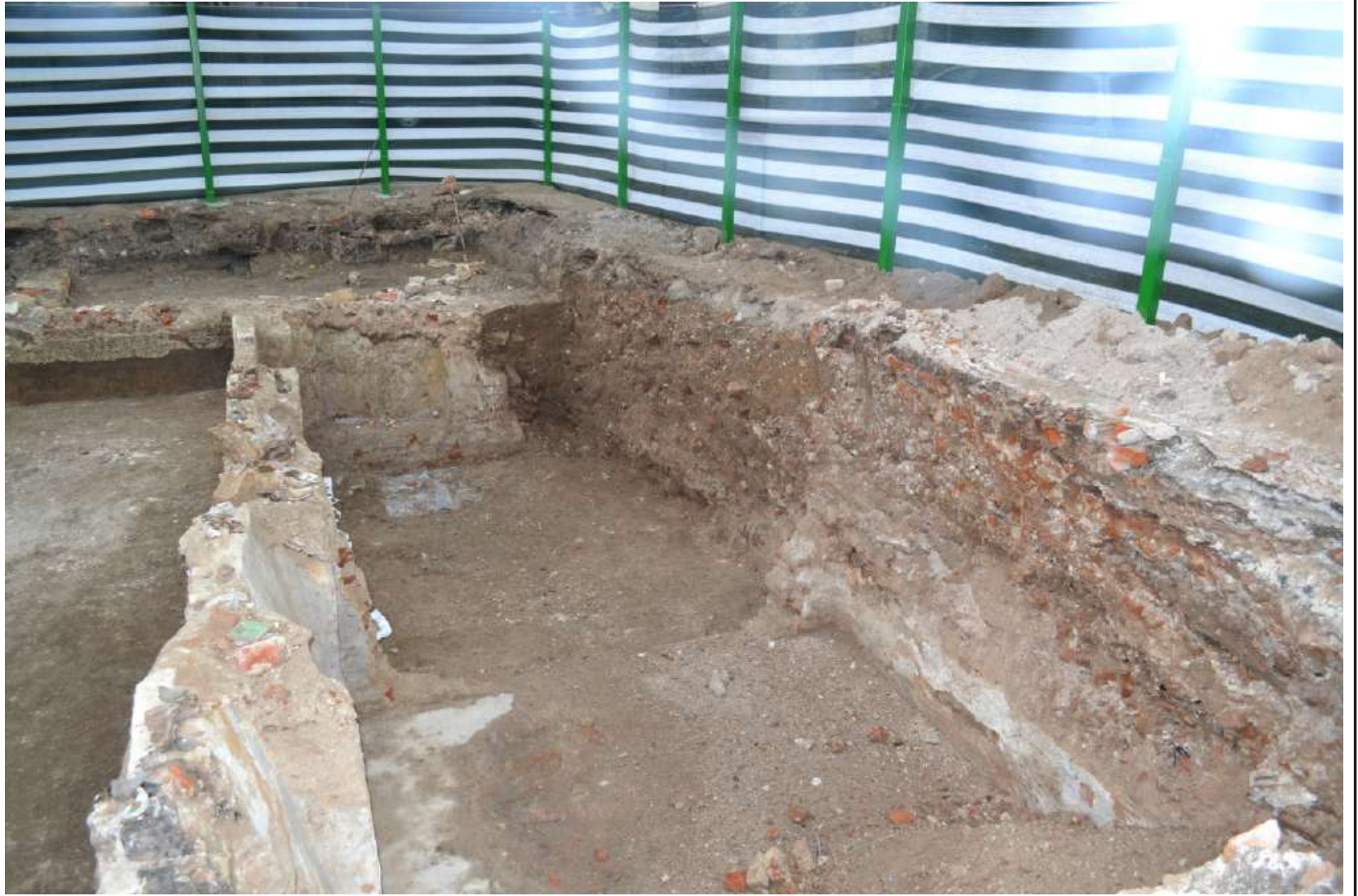

2 


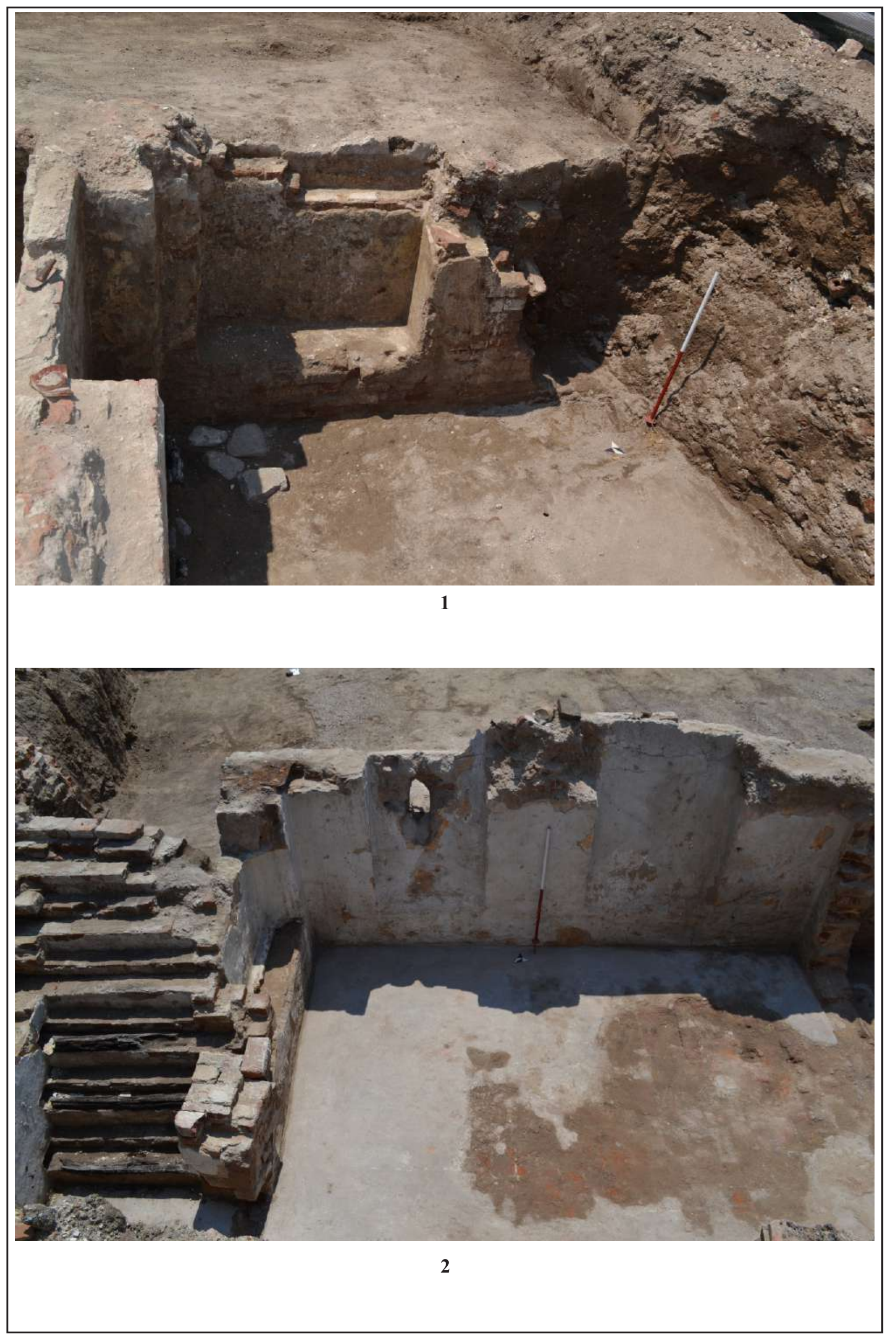

PI. XII 


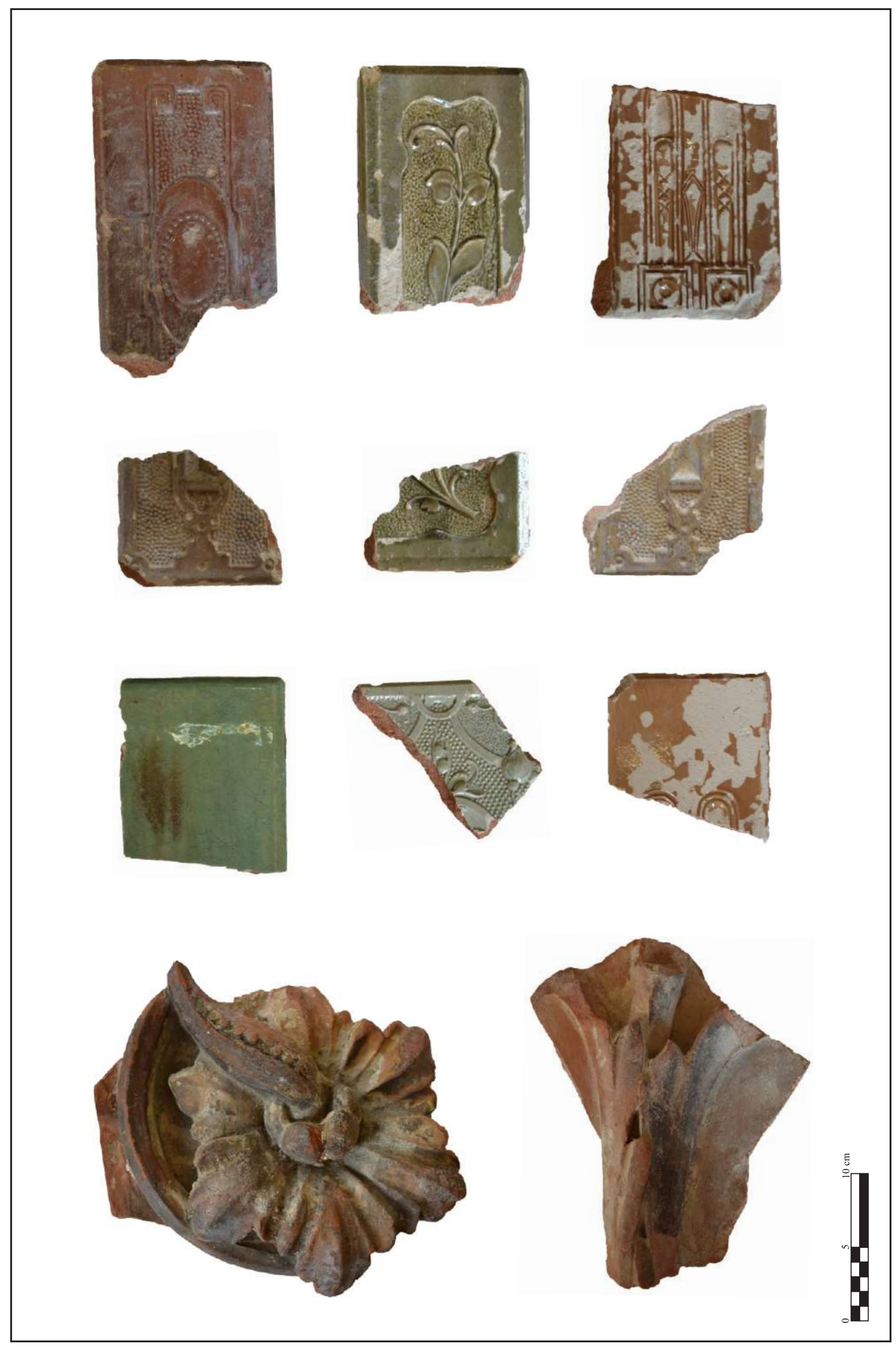

PI. XIII 


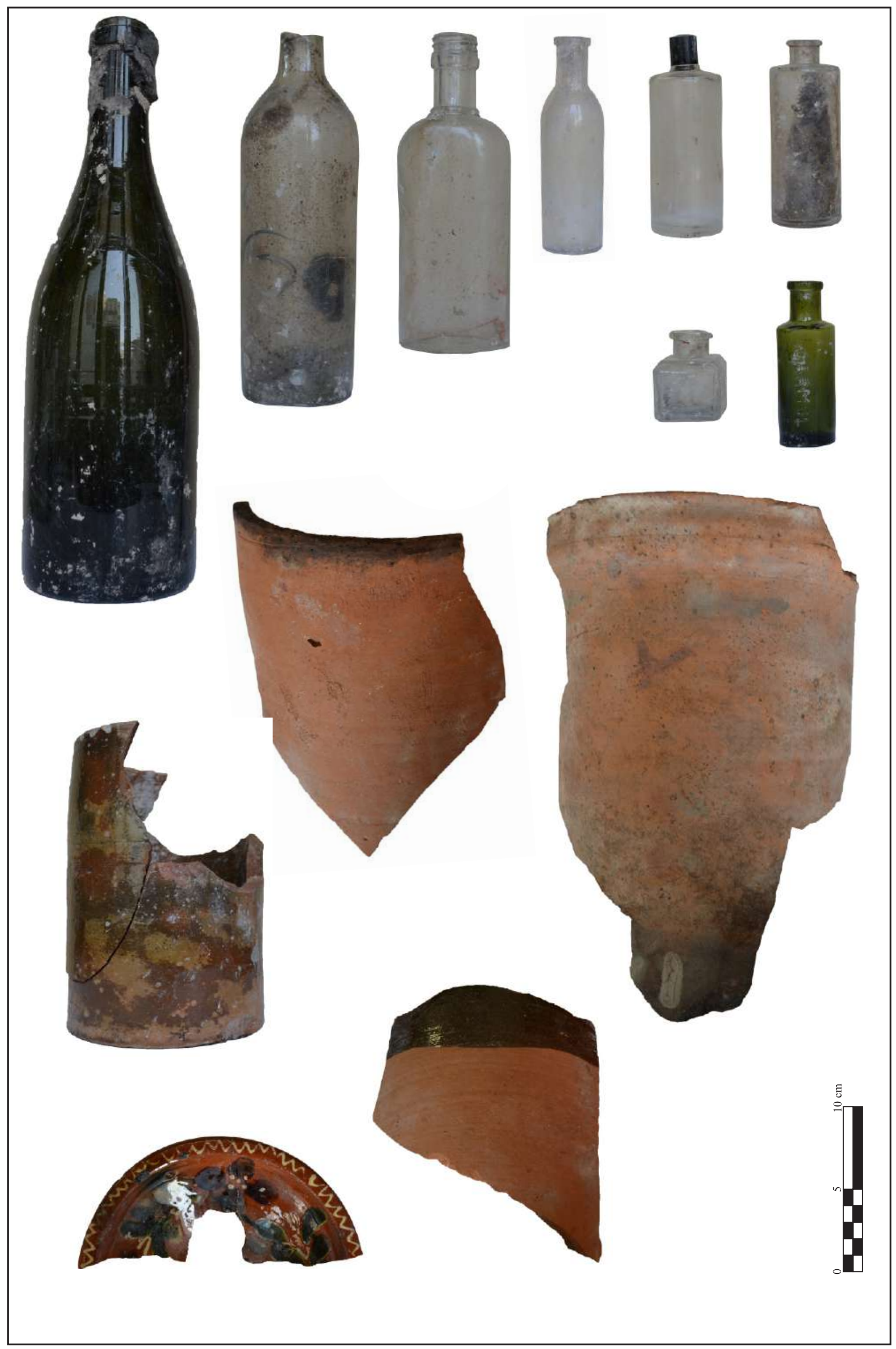

Pl. XIV 


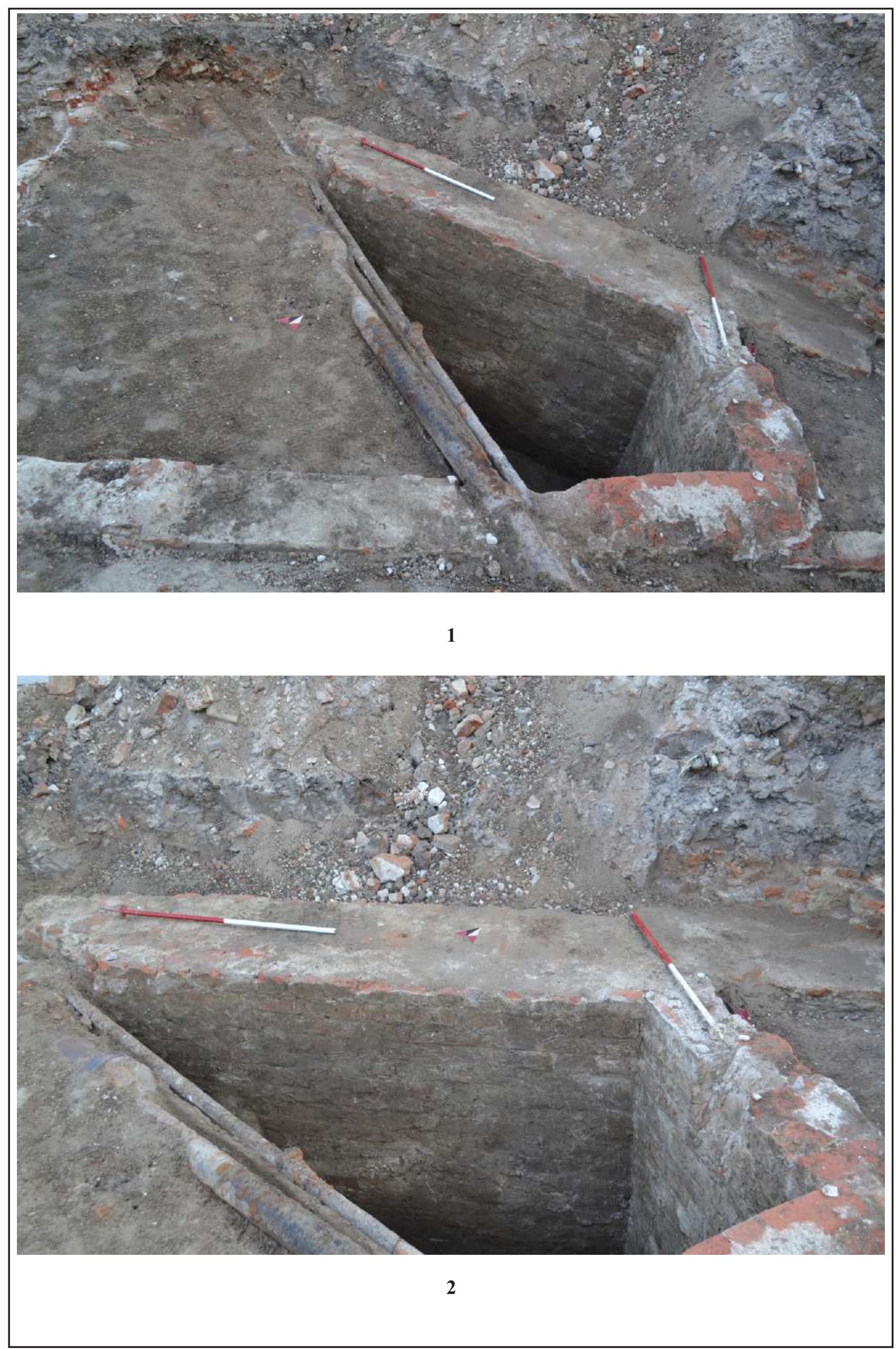

PI. XV 


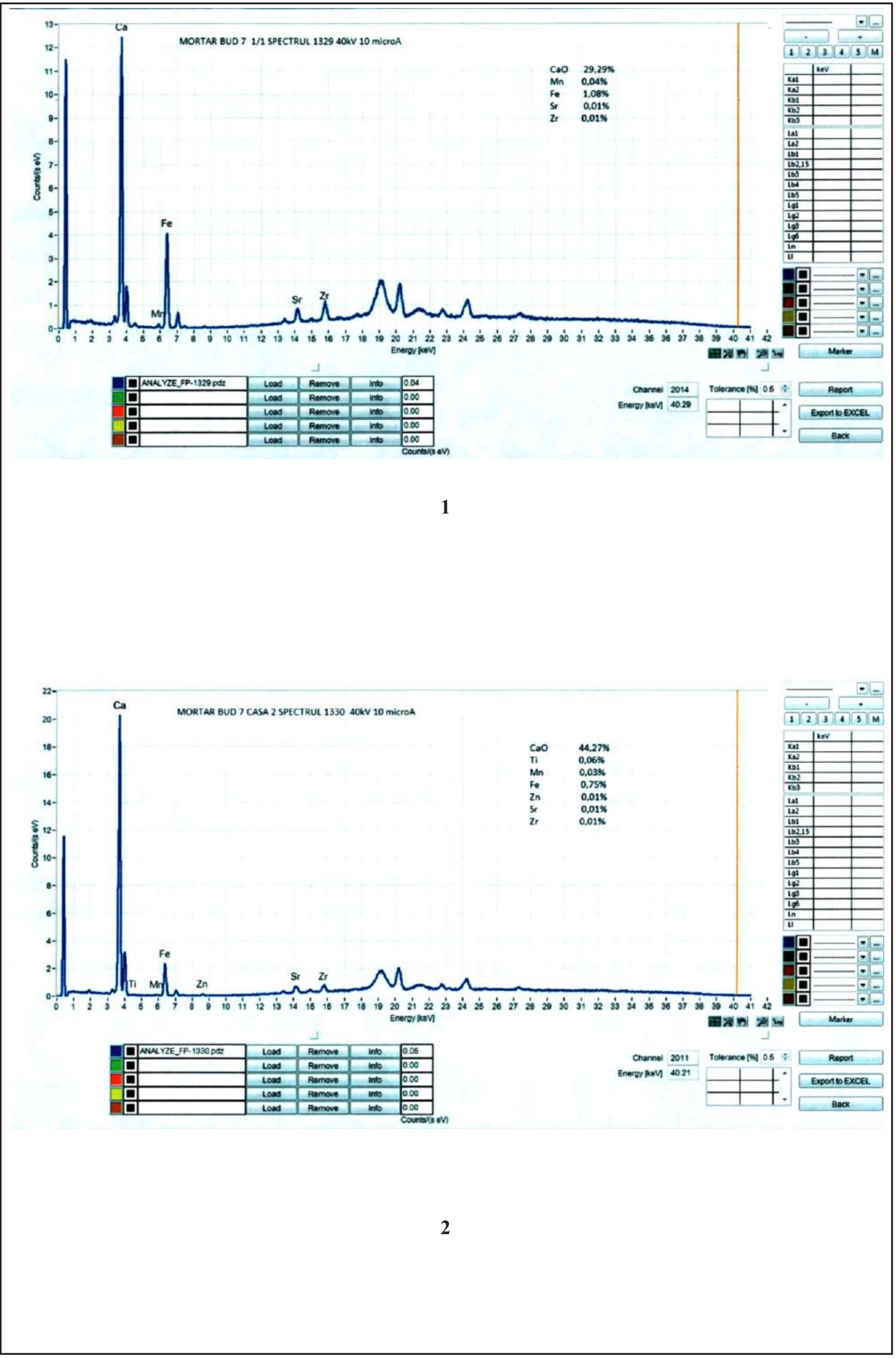




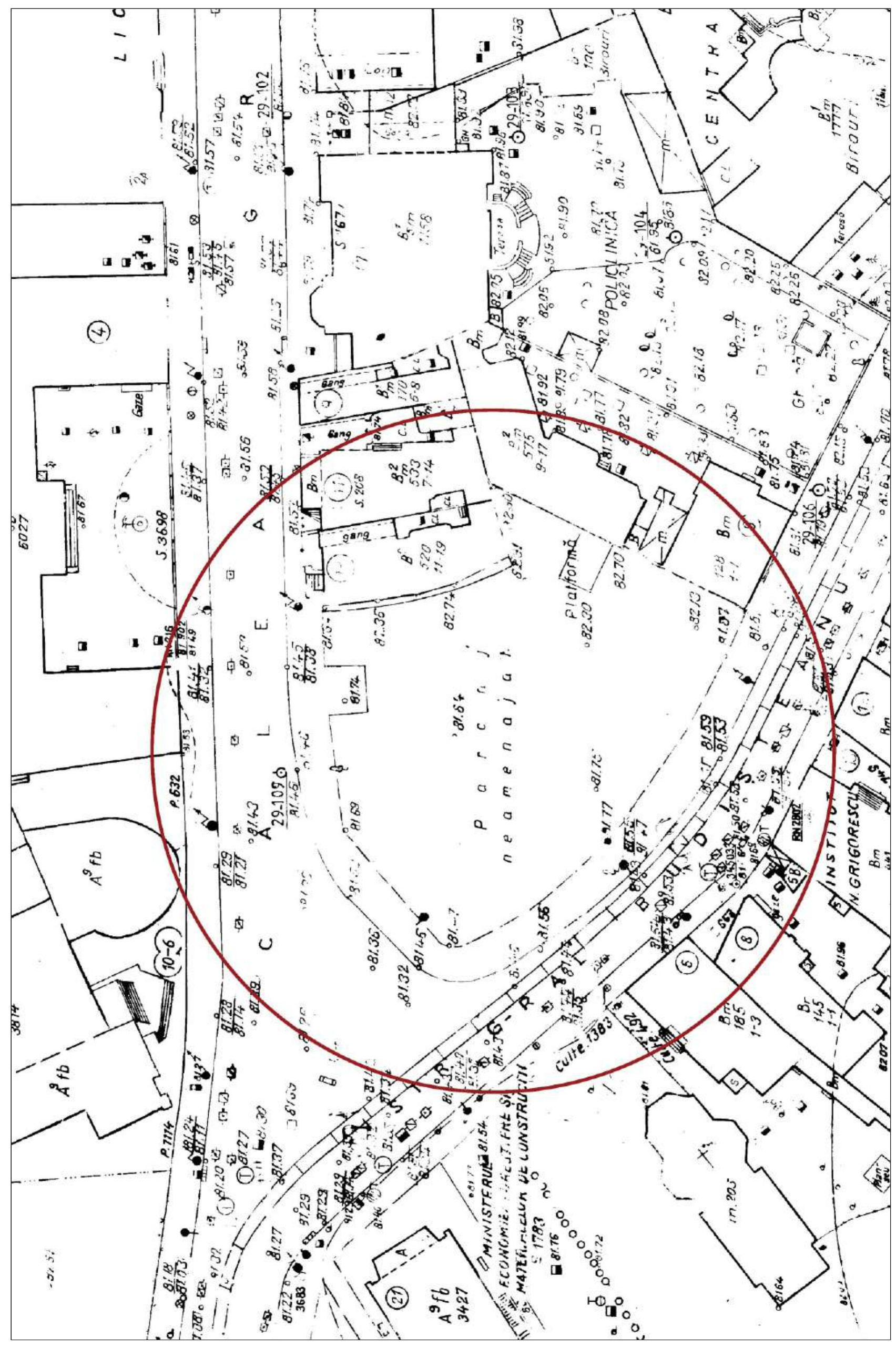




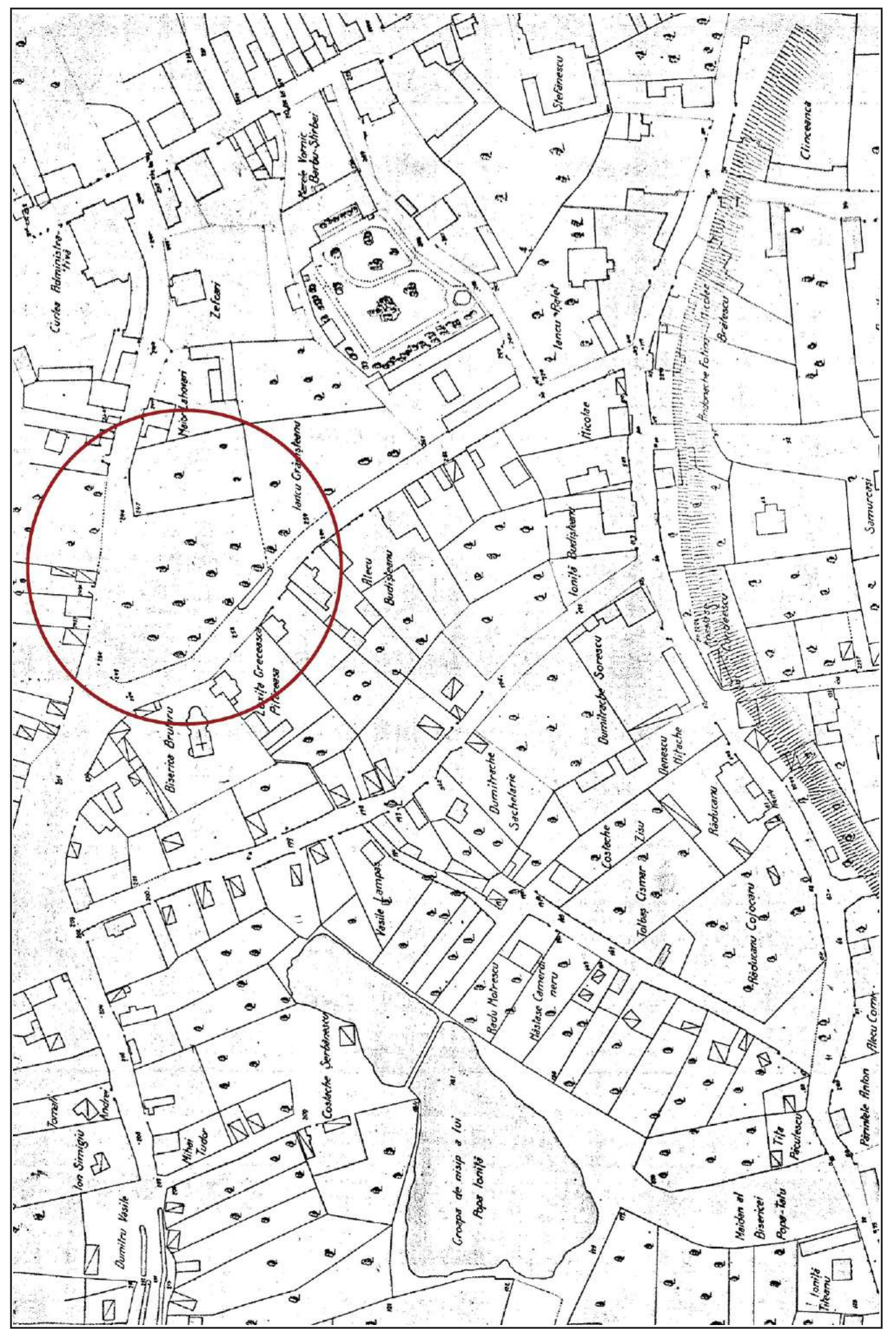




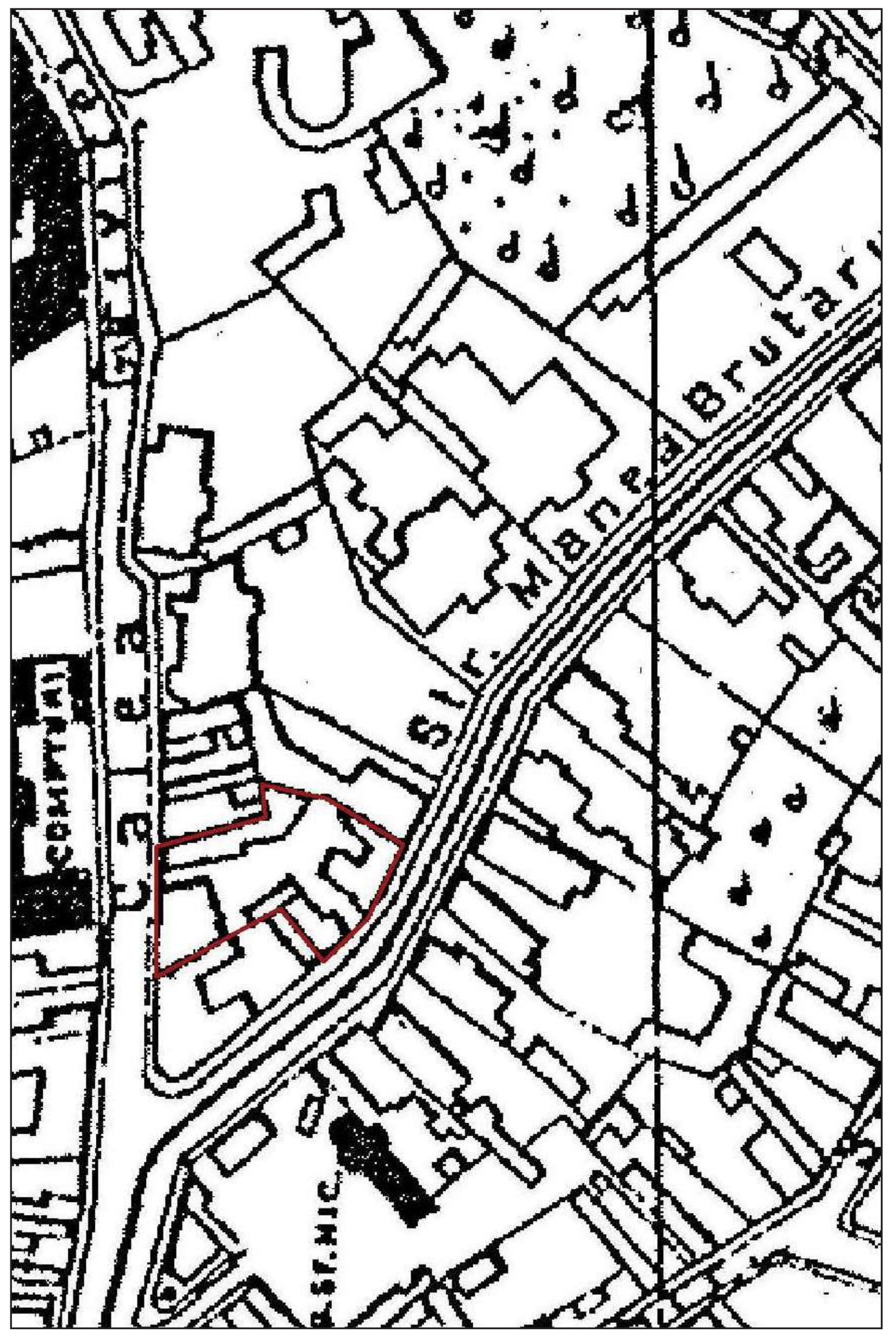




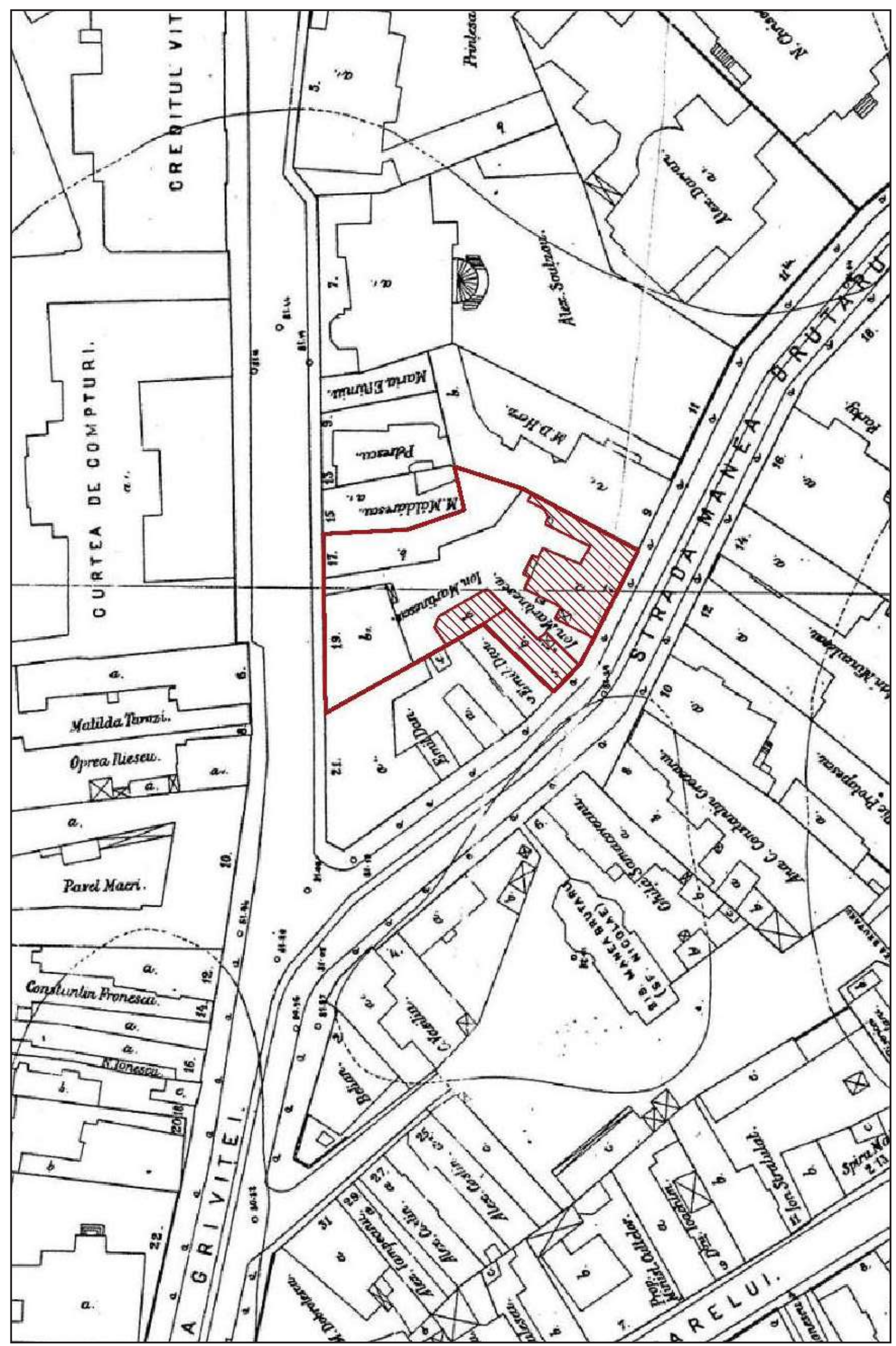

Pl. XX 


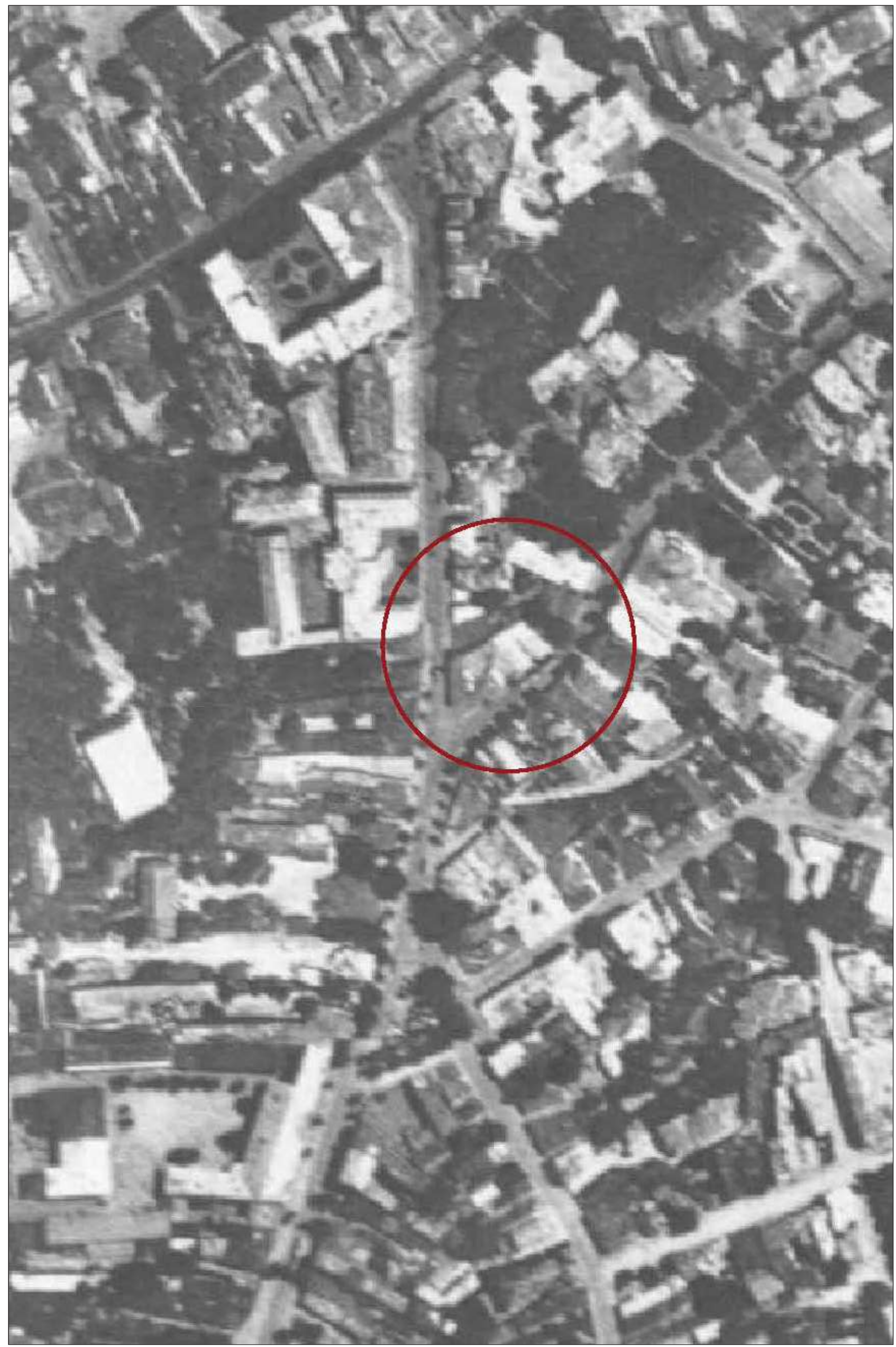




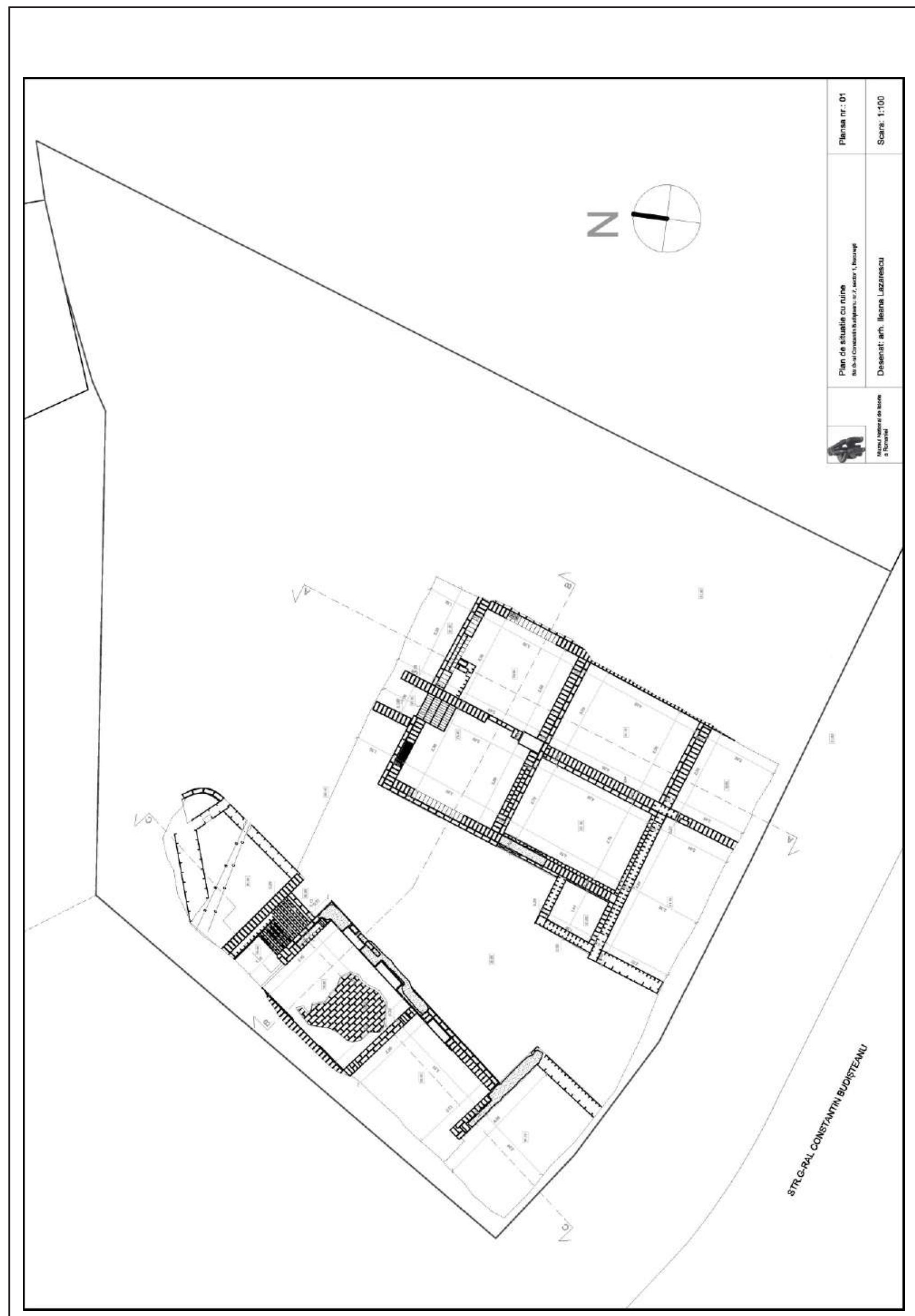

Pl. XXII 


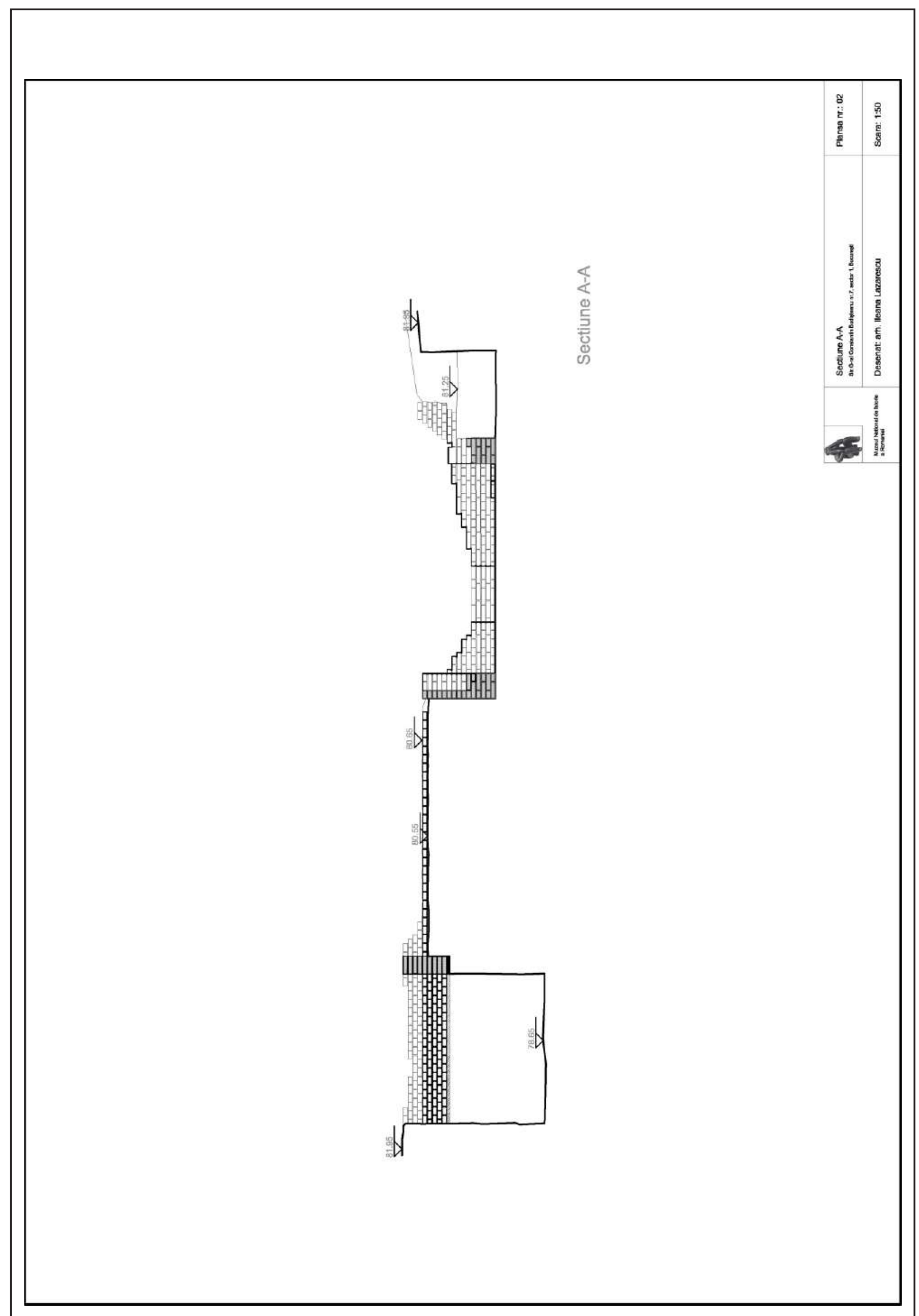

Pl. XXIII 


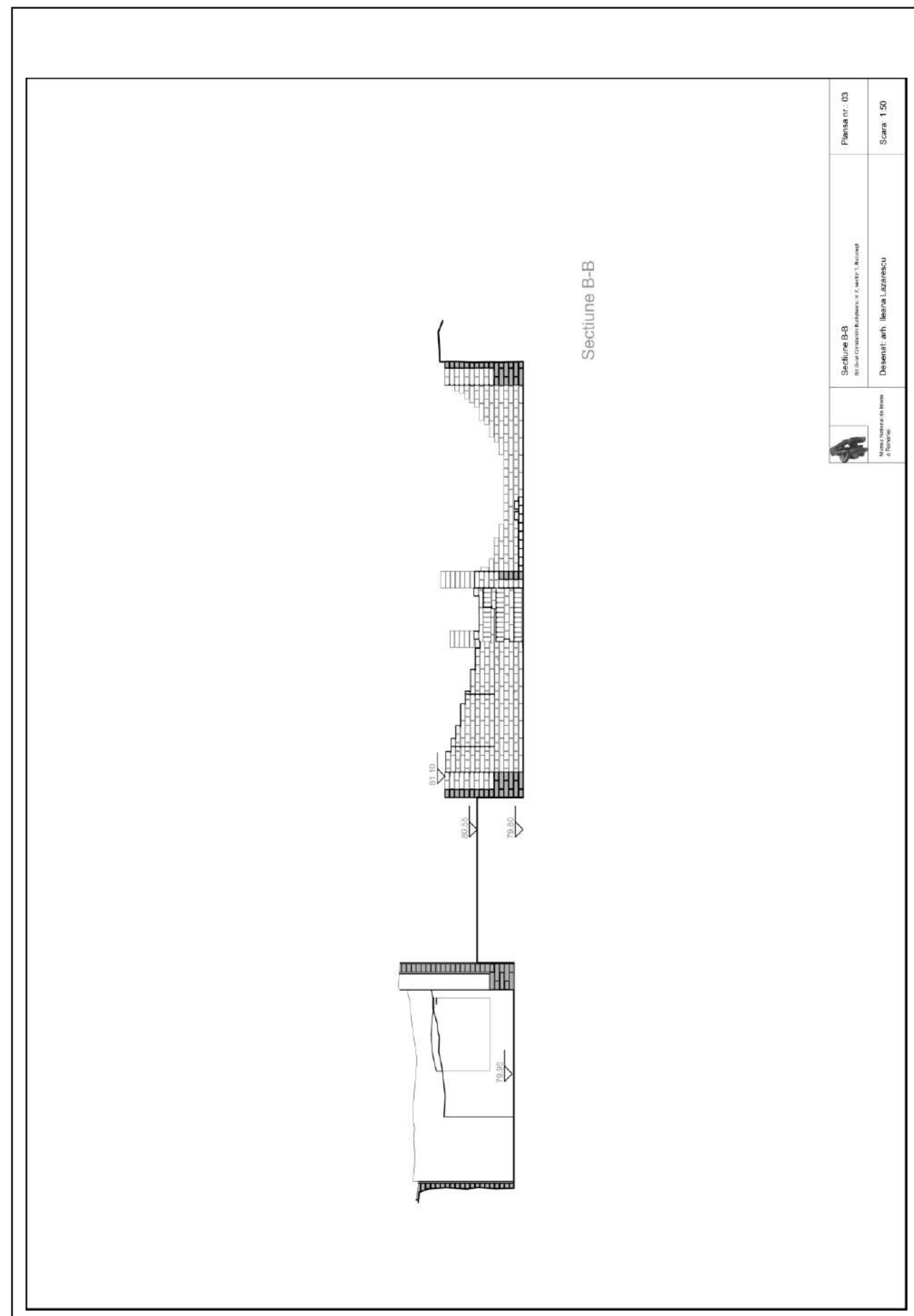

PI. XXIV 


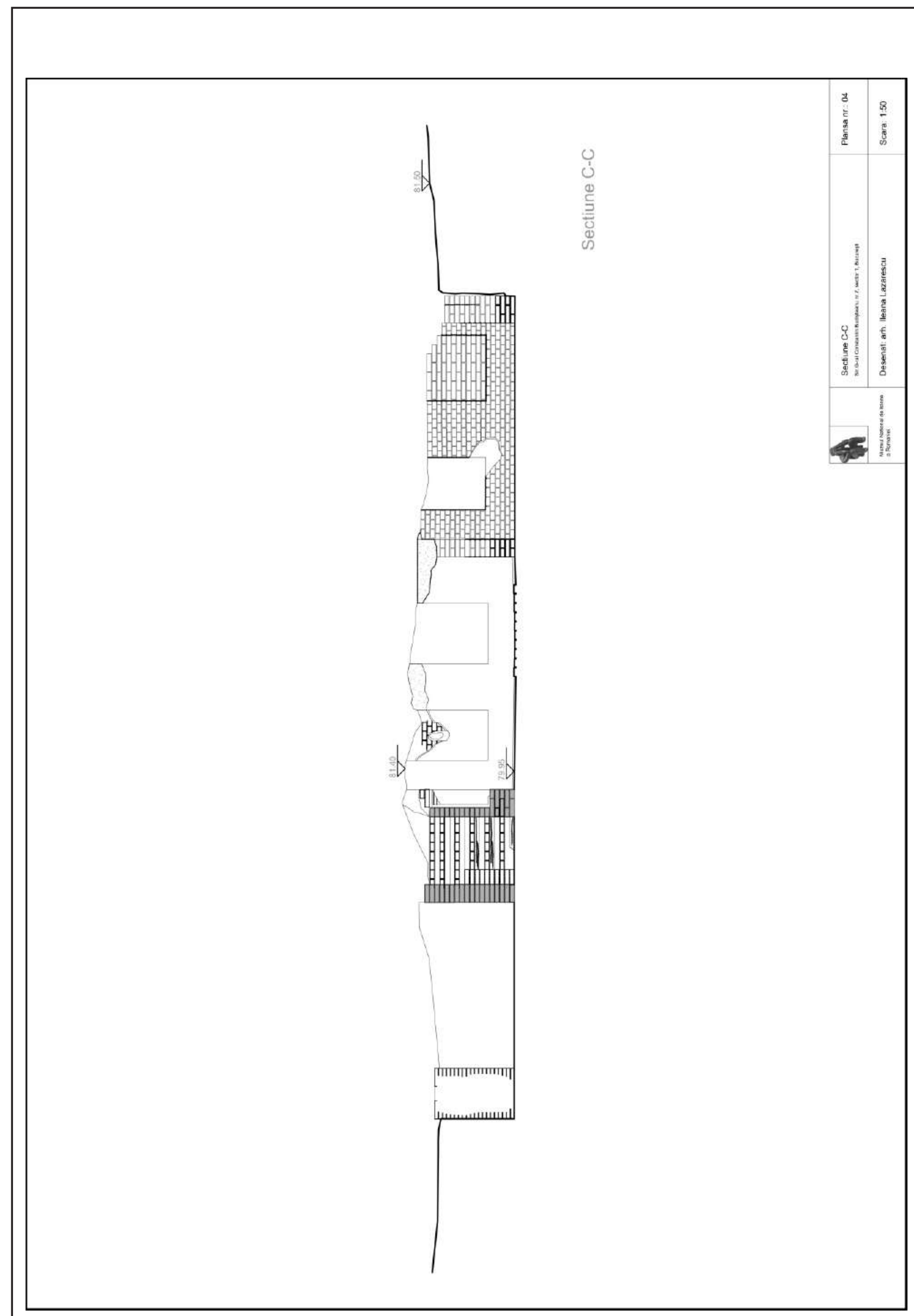

PI. XXV 


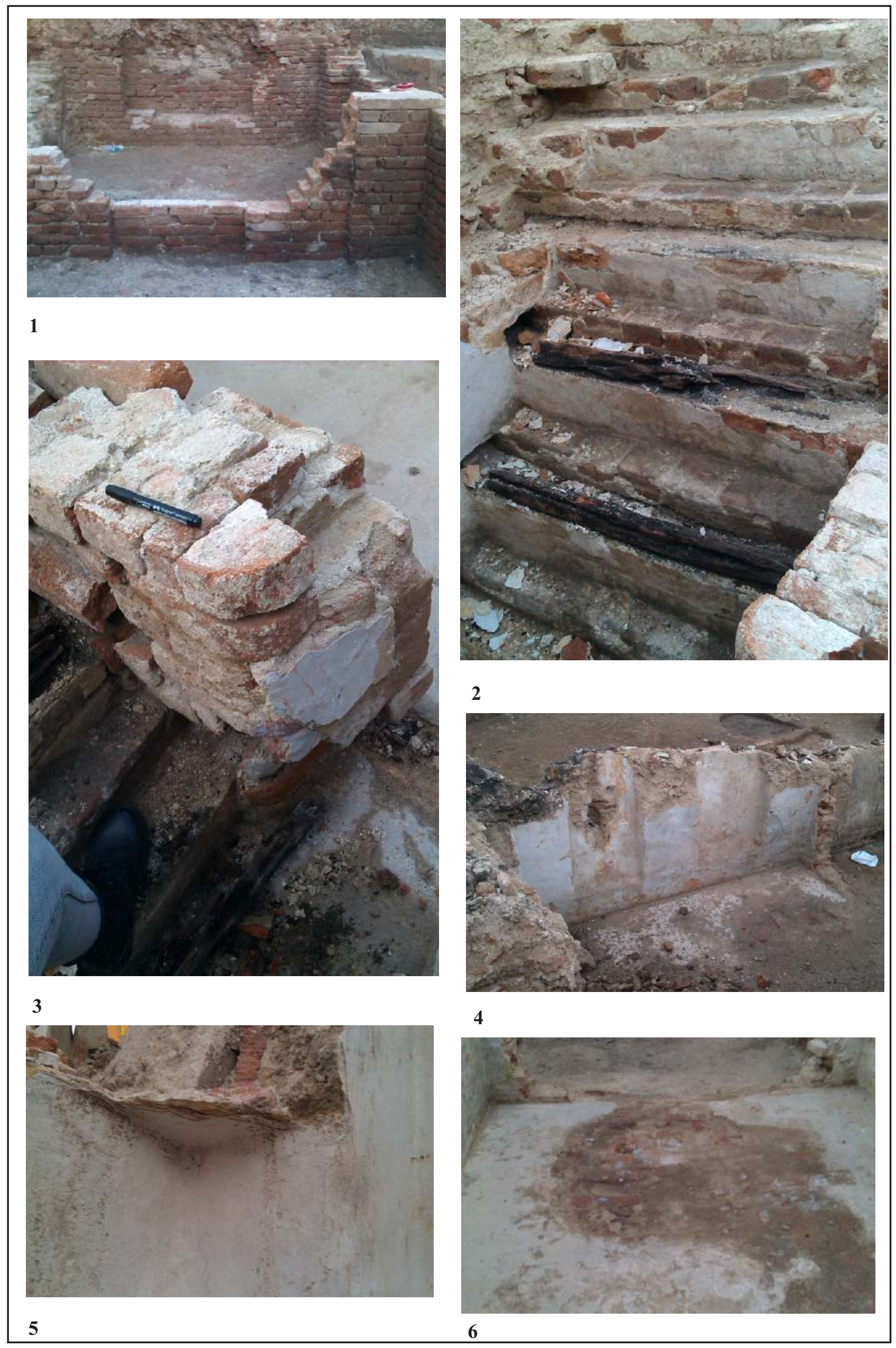

PI. XXVI 